Document downloaded from:

http://hdl.handle.net/10251/135401

This paper must be cited as:

Rius-Sorolla, G.; Maheut, J.; Estelles Miguel, S.; García Sabater, JP. (2020). Coordination mechanisms with mathematical programming models for decentralized decision-making, a literature review. Central European Journal of Operations Research. 28(1):61-104. https://doi.org/10.1007/s10100-018-0594-z

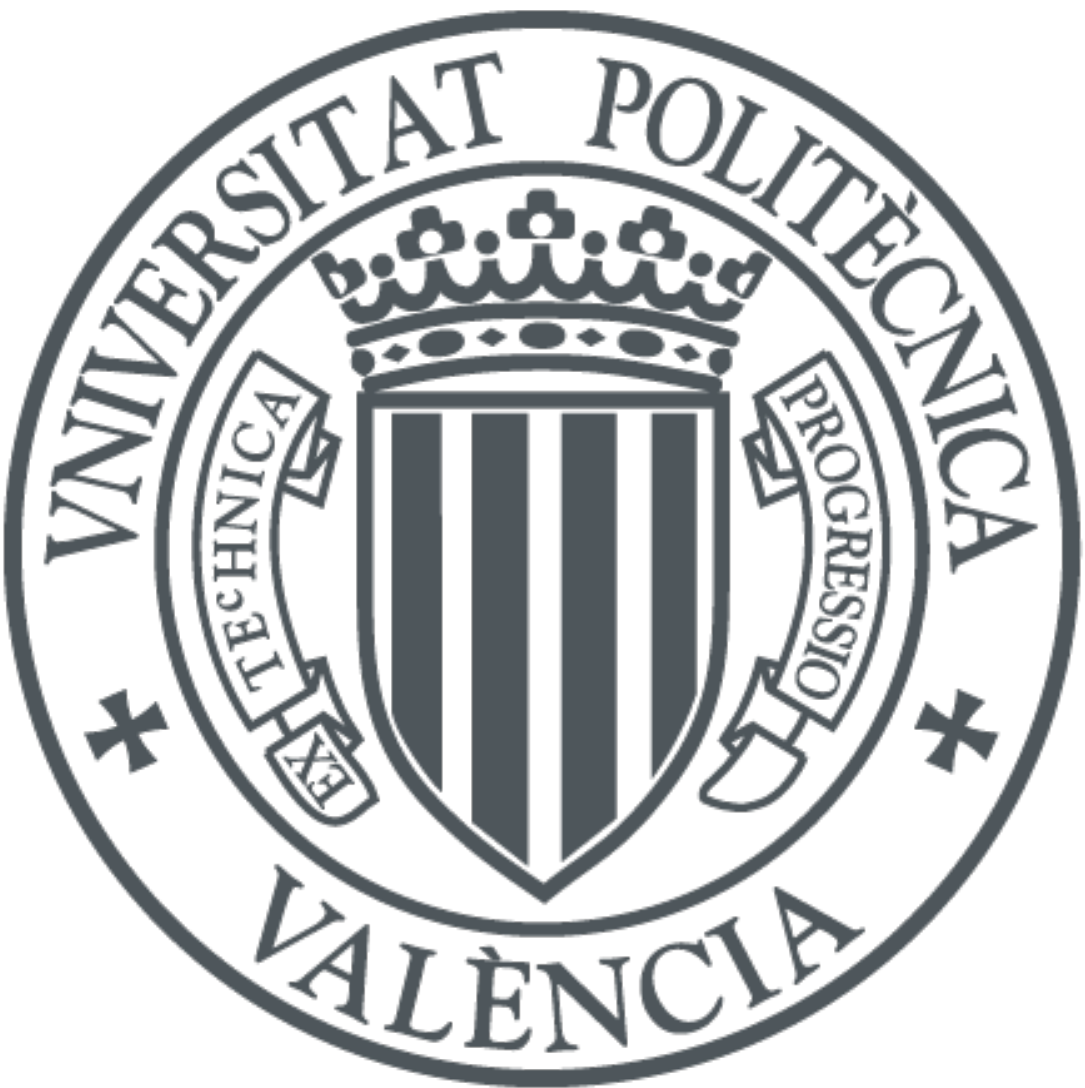

The final publication is available at

https://doi.org/10.1007/s10100-018-0594-z

Copyright Springer-Verlag

Additional Information 


\title{
Coordination mechanisms with mathematical programming models for decentralized decision-making, a literature review
}

\author{
Rius-Sorolla G', Maheut J, Estellés-Miguel S, Garcia-Sabater JP
}

\begin{abstract}
The increase in the complexity of supply chains requires greater efforts to align the activities of all its members in order to improve the creation of value of their products or services offered to customers. In general, the information is asymmetric; each member has its own objective and limitations that may be in conflict with other members. Operations managements face the challenge of coordinating activities in such a way that the supply chain as a whole remains competitive, while each member improves by cooperating. This document aims to offer a systematic review of the collaborative planning in the last decade on the mechanisms of coordination in mathematical programming models that allow us to position existing concepts and identify areas where more research is needed.
\end{abstract}

Keywords: systematic; coordination mechanism; deterministic; decentralized

\section{Introduction}

The new digital transformation era makes the coordination and coordination mechanisms research even more necessary. The Supply Chains (SC) are increasingly complex and distributed, composed by multiple organizations with different objectives and policies. Therefore, the SC have to coordinate their competitiveness when the end users do not need to know the location or characteristics of the required resources (Attanasio et al., 2006).

Since the first appearance of SC concept in 1982 (Cooper et al., 1997), it was identified that competition was barely between firms but between SC, that need to be coordinated. In fact, they have to manage the improvement among the SC members. Therefore, it is necessary to link the objectives and activities between the SC organizations, in order to achieve the optimization of the whole, instead of seeking only the myopic optimization of local results.

The breadth of coordination is between independent companies of a SC or inside clusters (Qu et al., 2015) or even within each organization (Behnamian, 2014). Stank (1999) studied the coordination processes within companies, which was characterized by effective communication, information exchange, partnership and performance monitoring. Since information is not equally available to all parties, asymmetric mechanisms are needed to ensure that the essential information is shared to make the right decisions (McAfee et al., 1987).

Coordination is not only necessary when factories are at different locations, with different cultures (Maheut et al., 2014a) but also among different time spans (Maheut et al., 2014b). These and other elements will affect decision making on storage and distribution location, production or distribution schedules, inventory planning, etc. Furthermore, different levels inside organizations that constitute the SC can be involved, which must be equally coordinated. All of them, with the objective to make optimal operational decisions for their organization and also to the SC (Ertogral et al., 2000).

Distributed asymmetric coordination mechanisms are necessary in organizations where centralized decision systems are impractical because their modelling is nonlinear and intractable, given the complexity of the facilities (Lu et al., 2012). So it is, when the Decision Systems are not able to react to

\footnotetext{
1e-mail: greriuso@upv.es Dpto. de Organización de Empresas. Universitat Politècnica de València, Camino de Vera s/n, 46022 Valencia.
} 
events in real time (Ouelhadj et al., 2009) or where reluctance to share information is found (Kutanoglu et al., 1999).

Sahin and Robinson (2002) proposed that information sharing and coordination among members were the main drivers of SC performance, examining the literature on integration in the SC. Effective information management generates a remarkable supply chain improvement (Zhou et al., 2007). Surveys demonstrate the correlation between improved benefits with information sharing, incentive alignment and decision synchronization (Sridharan et al., 2009).

In order to ensure coordination, contracts or mechanisms have been created (Whang, 1995) that allow local complexities to be managed, making decisions locally, wherever information is available, but taking into account global interests. The present work focuses on the mechanisms that allow the autonomous local planning and at the same time align the global interests through mathematical programming models.

Mechanisms must hold the right incentives to align objectives among different actors (Fan et al., 2003). For example, it is found proportional sharing of global benefits (Ben-Daya et al., 2008), transfer pricing, buyback, flexible delivery, rebate (Mahdiraji et al., 2015), quantity discount (Lehoux et al., 2014), credit period (Arkan et al., 2012), share of risk, quantity flexibility (Jeong 2012), franchise rights (Chakraborty et al., 2015), etc. Collaboration will only continue if cooperation is perceived to bring benefits or greater value to each party (Cheng, 2011). A fully integrated solution can result in optimum performance for the system (Buxmann et al., 2008), but such a solution may not always be in the best interest of each member of the system ( $\mathrm{Li}$ et al., 2007). Therefore, while in theory the best solution often means optimal, in practice, it will suffice that the results of the coordination have improved the overall result compared to the non-coordination (Stadtler et al., 2008).

Since the work of Dantzig-Wolfe (1960) and Benders (1962), different solutions have been devised with respect to the coordination of the SC. Important papers reviews such as (Arshinder et al., 2008; Badole et al., 2012; Jeong et al., 2002; Kumar et al., 2016; Li et al., 2007; Tang et al., 2016a), analyse different perceptions about the concept of "coordination" and the SC. But we find the literature review of Stadtler (2007) to be outstanding in its approach to coordination mechanisms of mathematical programming. That is why it has been started research in 2006 on coordination mechanisms in mathematical programming.

The main contribution of our work is to present a review of the main papers related to the coordination mechanism on mathematical programming in the last ten years and reviewed following the taxonomy given by Stadtler (2007) ten years ago.

The rest of the paper is structured as follows: first, a short description of the review methodology is introduced; second, a brief discussion of the results is presented; finally, the paper ends with a conclusion and future works.

\section{Review methodology}

The review has been carried out following the systematic literature review protocol presented and used by Marín et al. (2015) and Medina-Lopez et al. (2010).

The steps proposed are: set the goal, select type of reference and data base, search filter and manage reference, extract information of selected reference and write the report. Therefore, it uses transparent procedure, to find, evaluate and synthesize the results of relevant research. The procedures are explicitly defined in advance to ensure that the exercise is transparent and can be replicated. 
Our goal is to identify the coordination mechanisms for the allocation of resources and / or orders in the production planning between plants or companies within an organization or between different organizations within a supply chain.

Our databases are mainly the scientific-technical bibliographic databases of Scopus and Web of Science (WoS), with access from the Universitat Politècnica of València, from 2006 to 2016. It has been started from year 2006 since we consider as a starting point the review of coordination mechanisms presented by Stadtler (2007).

The search filter and inclusion criteria are related terms to our objectives of "coordination", "mechanism", "production", "deterministic" and "decentralized" (see Table 1). For example "collaboration", here, is referred to the means and efforts for common action between two or more parties in the SC, in order to obtain a better result than acting separately (Simatupang et al., 2006). Understanding that coordination requires collaboration (Albrecht, 2010).

Table 1 Search elements.

\begin{tabular}{ll}
\hline Search elements & Search elements complemented with additional related terms. \\
\hline Coordination & $\begin{array}{l}\text { "coordination" OR "collaboration" OR "collaborate" OR "cooperation" OR "cooperate" OR "balanced" OR } \\
\text { "coordinate" OR "participate" OR "collude" OR "conspire" OR "cooperate" OR " join force" OR " combine" }\end{array}$ \\
Mechanism & ("mechanism" OR "method" OR "system" OR "technique" OR "procedure" OR "instrument") \\
Decentral* & (decentral* OR "asymmetric") \\
Production & ("production" OR "scheduling") \\
Integer & "Integer" "deterministic" \\
\hline
\end{tabular}

Source: Own elaboration

The complete protocol and the search commands could be found in Rius-Sorolla et al. (2017). The results were 4.187 references preselected from the different search strategies and a resume could be viewed in Table 2.

Table 2 Preselected papers from the different search commands and duplicate works, self-made from Mendeley@ desktop.

\begin{tabular}{|c|c|c|c|c|c|c|c|}
\hline & & $\begin{array}{l}\text { First sea } \\
\text { Scopus } \\
\end{array}$ & First search & $\begin{array}{l}\text { Second search } \\
\text { WoS }\end{array}$ & \multicolumn{3}{|c|}{ Third Search } \\
\hline \multirow{2}{*}{ First search } & \multirow{2}{*}{$\begin{array}{l}\text { Scopus } \\
\text { WoS }\end{array}$} & 1.143 & 24 & 74 & 10 & 5 & 9 \\
\hline & & 24 & 35 & 19 & 0 & 0 & 0 \\
\hline Second search & WoS & 74 & 19 & 2.918 & 6 & 7 & 5 \\
\hline \multirow{3}{*}{ Third Search } & \multirow{3}{*}{$\begin{array}{l}\text { Scopus } \\
\text { WoS } \\
\text { Scholar }\end{array}$} & 10 & 0 & 6 & 105 & 62 & 89 \\
\hline & & 5 & 0 & 7 & 62 & 69 & 60 \\
\hline & & 9 & 0 & 5 & 89 & 60 & 186 \\
\hline
\end{tabular}

WoS Web of Science, Scholar scholar.google.com. Source: Own elaboration

The exclusion criteria were applied to those articles that provide works on the benefits of its implementation, without introducing coordination mechanisms, such as literature reviews. In addition, those from other areas such as power generation, multi-agent systems, sensors, etc. have been excluded. Additionally, papers that seek coefficients, values or equilibrium functions from unknown or non-discrete demands, fuzzy techniques, and models based on game theory have been excluded. Finally, the search excludes papers that propose algebraic solutions like Joint Economic Lot Size Models (JELS), contract theories, centralized solutions to the problem, dynamic programming or CPFR (Collaborative Planning, Forecasting, and Replenishment) or are not related to mathematical programming models, which deal with distributed decision-making. The inclusion criteria were broad enough to ensure that no mechanism 
is excluded, granting that the decision may generate numerous false positives. They can be found in (Rius-Sorolla et al., 2017), focused on publications using coordination mechanisms, applied or proposed for asymmetric information situations, decentralized and in the areas of production or production programming on tactical, operation or strategic decision level.

Therefore, the exclusion criteria were applied first to their titles and summaries, and in a second phase to the full text review. A total of 59 papers have been selected for reviewing. Most of the citations were found on journals $(89.7 \%)$, the others from conference (10.3\%) (see Table 4). Six journals accounted for the $39.7 \%$ of the citations: International Journal of Production Economics, International Journal of Production Research Computers \& Chemical Engineering, European Journal of Operational Research, IEEE Transactions on Automation Science and Engineering and Operations Research (see Table 4). Table 3 shows the distribution of the coordination mechanism applied by years. For the 59 articles reviewed 18 are based on the Lagrangian Relaxation (LR) with different heuristic to update the multiplier, 13 have used different meta-heuristics $(\mathrm{MH})$ to find a coordination scene, 16 have used a hierarchy based protocol (HBP), 7 have used the Dantzig-Wolfe (DW) (1960) method, 4 have used auction mechanism (AM) to update the assignment and one has used Benders (1962) method.

Table 3 Coordination mechanism of the selected references.

\begin{tabular}{|c|c|c|c|c|c|c|c|c|c|c|c|c|}
\hline Mechanism & 2006 & 2007 & 2008 & 2009 & 2010 & 2011 & 2012 & 2013 & 2014 & 2015 & 2016 & Total \\
\hline Benders & & & & & & & & & 1 & & & 1 \\
\hline $\mathbf{A M}$ & 1 & 1 & & & & 1 & & & & & 1 & 4 \\
\hline DW & & 1 & 1 & & 1 & & & & 2 & 3 & & 7 \\
\hline НBP & 1 & 1 & 3 & & 4 & & & 2 & 1 & 1 & 3 & 16 \\
\hline MH & & 1 & & 1 & 2 & 2 & & 2 & 1 & 4 & & 13 \\
\hline LR & & & 3 & 2 & 1 & 2 & 1 & 1 & 1 & 2 & 4 & 18 \\
\hline Total & 2 & 4 & 7 & 3 & 8 & 5 & 1 & 5 & 6 & 10 & 8 & 59 \\
\hline
\end{tabular}

Benders decomposition approach from Benders (1962), $A M$ action mechanism, $D W$ as the Dantzig-Wolf (1960), $H B P$ Hierarchy bases protocol, $M H$ meta-heuristics $L R$ Lagrangian relaxation

Table 4 Journal or conference of the selected references.

\begin{tabular}{|c|c|c|}
\hline Publication & References & $\%$ Total \\
\hline International Journal of Production Economics & 9 & $15 \%$ \\
\hline International Journal of Production Research & 4 & $7 \%$ \\
\hline Computers \& Chemical Engineering & 3 & $5 \%$ \\
\hline European Journal of Operational Research & 3 & $5 \%$ \\
\hline Computers \& Industrial Engineering & 2 & $3 \%$ \\
\hline IEEE Transactions on Automation Science and Engineering & 2 & $3 \%$ \\
\hline Operations Research Letters & 2 & $3 \%$ \\
\hline 2010 International Conference on Systems Sciences & 1 & $2 \%$ \\
\hline 2010 World conference on Transport Research & 1 & $2 \%$ \\
\hline 2013 International Conference on Advanced Logistics and Transport, ICALT 2013 & 1 & $2 \%$ \\
\hline 2014 IEEE Computational Intelligence in Production and Logistics Systems & 1 & $2 \%$ \\
\hline 2015 48th Hawaii International Conference on System Sciences & 1 & $2 \%$ \\
\hline 2015 IEEE Symposium Series on Computational Intelligence (IEEE Ssci) & 1 & $2 \%$ \\
\hline 2016 European Control Conference, ECC 2016 & 1 & $2 \%$ \\
\hline Agricultural Systems & 1 & $2 \%$ \\
\hline Applied Soft Computing & 1 & $2 \%$ \\
\hline Automatisierungstechnik & 1 & $2 \%$ \\
\hline Building and Environment & 1 & $2 \%$ \\
\hline Canadian journal of forest & 1 & $2 \%$ \\
\hline Computers and Chemical Engineering & 1 & $2 \%$ \\
\hline
\end{tabular}




\begin{tabular}{|c|c|c|}
\hline Discrete Applied Mathematics & 1 & $2 \%$ \\
\hline Electronic Commerce Research & 1 & $2 \%$ \\
\hline European J. of Industrial Engineering & 1 & $2 \%$ \\
\hline Forest Science & 1 & $2 \%$ \\
\hline IEEE Transactions on Systems, Man, and Cybernetics & 1 & $2 \%$ \\
\hline IFAC-PapersOnLine & 1 & $2 \%$ \\
\hline International Journal of Computer Integrated Manufacturing & 1 & $2 \%$ \\
\hline International Journal of Industrial Engineering: Theory Applications and Practice & 1 & $2 \%$ \\
\hline International Journal of Information Processing and Management & 1 & $2 \%$ \\
\hline International Journal of Information Technology \& Decision Making & 1 & $2 \%$ \\
\hline International Journal of Shipping and Transport Logistics & 1 & $2 \%$ \\
\hline International Transactions in Operational Research & 1 & $2 \%$ \\
\hline Journal of Engineering and Technology Management & 1 & $2 \%$ \\
\hline Journal of Manufacturing Systems & 1 & $2 \%$ \\
\hline Journal of Operations Research Quarterly & 1 & $2 \%$ \\
\hline Journal of Process Control & 1 & $2 \%$ \\
\hline Journal of the Operational Research Society & 1 & $2 \%$ \\
\hline Lecture Notes in Computer Science & 1 & $2 \%$ \\
\hline Logistics Management & 1 & $2 \%$ \\
\hline Parallel Computing & 1 & $2 \%$ \\
\hline Production Planning \& Control & 1 & $2 \%$ \\
\hline
\end{tabular}

\section{Research on coordination mechanism}

As a reference framework, in order to describe the main characteristics observed in the selected literature, it will be used part of the taxonomy already proposed by Stadtler (2007) and part used by Mula et al. (2010) which is described in Rius-Sorolla et al. (2017), all of them are briefly described below:

Temporal level of the coordinated decision: Classify coordinated decisions based on the temporal scope, with the denomination of strategic or long-term, tactical or medium-term, and finally operational or shortterm.

Structure and relationship between the members of the SC: It identifies the SC levels, the number of members in each level and the business that will be coordinated.

Type of relationship between members of the SC: This approach consists in identifying if one of the members has more power than the other. In addition, the type of expected behaviour among members or behavioural assumptions is analysed, such as opportunistic or team behaviour or if possible opportunistic behaviours are evaluated. In addition, it includes the possible effects of learning in the negotiation and, finally, if the planning is proposed throughout the periods as rolling horizons.

Objectives of coordination mechanism: Identification of the purpose of the coordination mechanism, how to align the requirements, which the supplier can satisfy the customer's requirements, or seek an optimal solution of the SC or a solution that works in a fair share of the coordination benefits.

Models and steps in collaboration: This presents the type of mathematical programming model used to coordinate. Then, the phase in which the negotiation is considered. That is, if it is in the phase in which the collaboration conditions are negotiated, or in the planning, or in the execution phase, or finally in the evaluation phase, which allows the conditions to be renegotiated for the next phase. In addition, what information is shared to reach the collaboration and what is hidden by each member. 
Characteristics of the implementation of the mechanism: This presents the type of mechanism and, if necessary, the figure of a mediator, the member who must originate the first proposal and the negotiation phases that must be exchanged to arrive at a solution and, finally, if compensation is proposed.

Solutions quality and novelty: It includes the way in which the works evaluate the proposed solutions. It identifies the works that provide a demonstration of the convergence of the method. It determines those papers that perform a simulation of a case study; therefore, the evidence of the method will be limited to this situation. On the other hand, other works define a series of parameters and computational tests to validate said situations.

\subsection{Temporal level of the coordinated decision}

Huang et al. (2003) proposed as criteria to classify the temporal span of the decision. They define strategic decisions, in the long term, from 6 months to two years, such as pricing, postponement, capacity allocation, facility allocation. The tactical level is in the medium term, 2 weeks to 6 months, the decisions of safety stock, shipment plan, material requirement planning and production \& transport plan. Finally, the operational decisions are in the short term, the daily decisions, those of ordering, inventory allocation, production scheduling and vehicle routing. In the 59 papers, the deadlines or the decisions level are not always defined by the authors. For example, Albrecht et al. (2015) present a proposal for a generic coordination mechanism for Sales and Operations Planning (S\&OP), which could be both on a strategic or tactical level, but we opt for the tactical since they act more on production planning (see Table 5).

Table 5 Time decision level of reviewed works.

\begin{tabular}{|c|c|c|c|}
\hline Authors & Strategic & Tactical & Operational \\
\hline (Agnetis et al., 2006) & & & $\mathrm{x}$ \\
\hline (Attanasio et al., 2006) & & & $\mathrm{x}$ \\
\hline (Dash et al., 2007) & & $\mathrm{x}$ & \\
\hline (Dudek et al., 2007) & & $\mathrm{x}$ & \\
\hline (Pibernik et al., 2007) & & $\mathrm{x}$ & \\
\hline (Pittman et al., 2007) & & $\mathrm{x}$ & \\
\hline (Cheng et al., 2008) & & & $\mathrm{x}$ \\
\hline (Feng et al., 2008) & $\mathrm{x}$ & $\mathrm{x}$ & $\mathrm{x}$ \\
\hline (Jung et al., 2008) & & & $\mathrm{x}$ \\
\hline (Kelly et al., 2008) & & & $\mathrm{x}$ \\
\hline (Nie et al., 2008) & & $\mathrm{x}$ & \\
\hline (Nishi et al., 2008) & & & $\mathrm{x}$ \\
\hline (Walther et al., 2008) & & $\mathrm{x}$ & \\
\hline (Jeong et al., 2009) & & & $\mathrm{x}$ \\
\hline (Pukkala et al., 2009) & & $\mathrm{x}$ & \\
\hline (Silva et al., 2009) & & $\mathrm{x}$ & $\mathrm{x}$ \\
\hline (Frazzon et al., 2010) & & & $\mathrm{x}$ \\
\hline (Gaudreault et al., 2010) & & $\mathrm{x}$ & \\
\hline (Gunnerud et al., 2010) & & & $\mathrm{x}$ \\
\hline (Homberger, 2010) & & $\mathrm{x}$ & \\
\hline (Homberger et al., 2010) & & $\mathrm{x}$ & \\
\hline (Lee et al., 2010) & & $\mathrm{x}$ & \\
\hline (Lehoux et al., 2010a) & & $\mathrm{x}$ & \\
\hline (Lehoux et al., 2010b) & & $\mathrm{x}$ & \\
\hline (Homberger et al., 2011) & & $\mathrm{x}$ & \\
\hline (Homberger, 2011) & & $\mathrm{x}$ & \\
\hline (Lau et al., 2011) & & & $\mathrm{x}$ \\
\hline (Mouret et al., 2011) & & & $\mathrm{x}$ \\
\hline
\end{tabular}




\begin{tabular}{|lll|}
\hline (Singh et al., 2011) & & \\
\hline (Lu et al., 2012) & x & \\
\hline (Buer et al., 2013) & $\mathrm{x}$ & \\
\hline (Kovács et al., 2013) & $\mathrm{x}$ & \\
\hline (Taghipour et al., 2013) & $\mathrm{x}$ & \\
\hline (Thomas et al., 2013) & $\mathrm{x}$ & \\
\hline (Ziebuhr et al., 2013) & $\mathrm{x}$ & \\
\hline (Behnamian, 2014) & $\mathrm{x}$ & $\mathrm{x}$ \\
\hline (Kong et al., 2014) & $\mathrm{x}$ & \\
\hline (Lehoux et al., 2014) & $\mathrm{x}$ & \\
\hline (Reiss et al., 2014) & $\mathrm{x}$ & \\
\hline (Sokoler et al., 2014) & $\mathrm{x}$ & $\mathrm{x}$ \\
\hline (Thomas et al., 2014) & & $\mathrm{x}$ \\
\hline (Acar et al., 2015) & $\mathrm{x}$ & $\mathrm{x}$ \\
\hline (Albrecht et al., 2015) & $\mathrm{x}$ & \\
\hline (Buer et al., 2015) & $\mathrm{x}$ & \\
\hline (Eslikizi et al., 2015) & $\mathrm{x}$ & $\mathrm{x}$ \\
\hline (Harb et al., 2015) & $\mathrm{x}$ & $\mathrm{x}$ \\
\hline (Homberger et al., 2015) & $\mathrm{x}$ & \\
\hline (Mason et al., 2015) & $\mathrm{x}$ & \\
\hline (Qu et al., 2015) & $\mathrm{x}$ & \\
\hline (Thomas et al., 2015) & $\mathrm{x}$ & \\
\hline (Ziebuhr et al., 2015) & $\mathrm{x}$ & \\
\hline (Agnetis et al., 2016) & $\mathrm{x}$ & $\mathrm{x}$ \\
\hline (Bajgiran et al., 2016) & $\mathrm{x}$ & \\
\hline (Jia et al., 2016) & $\mathrm{x}$ & \\
\hline (Singh et al., 2016) & $\mathrm{x}$ & \\
\hline (Tang et al., 2016b) & & \\
\hline (Wenzel et al., 2016a) & & \\
\hline (Wenzel et al., 2016b) & $\mathrm{x}$ & \\
\hline (Zoghlami et al., 2016) & & \\
\hline & & \\
\hline
\end{tabular}

As can be seen, only four of the studies consider coordination in strategic decisions, in the long term, where two of them are related to forest problems and the wood industry (Feng et al., 2008; Kong et al., 2014) since the periods of optimum forest growth are around 25 years. Lu et al. (2012) pose a localization problem, with a mediator-free coordination based on the human immune system. Qu et al. (2015) solve a problem of configuring a cluster by means of the augmented Lagrange or updating the Lagrange multiplier using the quadratic function.

\subsection{Structure and relationship between the members of the SC}

The SC structure is one of the main factors in the complexity of aligning the plans of the different organizations in order to achieve coordination (Stadtler, 2007). Such complexity will influence the type of information shared, the generation of trust and the quality of shared information. It will be defined the structure of the SC (see Table 6) by the number of tiers, members at each level, the business area to be coordinated and whether coordination is between different organizations (inter) or within the same organization (intra).

Table 6 Structure of the organization on reviewed works.

\begin{tabular}{lllll}
\hline Author & $\mathbf{N}^{0}$ of tiers & $\mathbf{N}^{\circ}$ of members on & Business functions & Intra or inter \\
\hline
\end{tabular}




\begin{tabular}{|c|c|c|c|c|}
\hline & & tiers & & \\
\hline (Agnetis et al., 2006) & 2 & $1-n$ & Prod & Inter \\
\hline (Attanasio et al., 2006) & 2 & $\mathrm{n}-1$ & Prod & Inter \\
\hline (Dash et al., 2007) & 2 & $n-n$ & Prod & Inter \\
\hline (Dudek et al., 2007) & 2 & $1-n$ & prod & Inter \\
\hline (Pibernik et al., 2007) & 2 & $n-n$ & prod, distr & Inter \\
\hline (Pittman et al., 2007) & 1 & $\mathrm{n}$ & prod & Intra \\
\hline (Cheng et al., 2008) & 1 & $\mathrm{n}$ & prod & Intra \\
\hline (Feng et al., 2008) & 3 & $n-n-n$ & prod, distr, sales & Intra \\
\hline (Jung et al., 2008) & 2 & $1-1$ & prod, distr & Inter \\
\hline (Kelly et al., 2008) & 2 & $n-n$ & prod & Intra \\
\hline (Nie et al., 2008) & $\mathrm{n}$ & $\mathrm{n}$ & prod & Inter \\
\hline (Nishi et al., 2008) & 2 & $1-n$ & prod & Inter \\
\hline (Walther et al., 2008) & 2 & $\mathrm{n}-1$ & prod, distr & Inter \\
\hline (Jeong et al., 2009) & 1 & $1-1$ & prod & Intra \\
\hline (Pukkala et al., 2009) & 1 & $\mathrm{n}$ & prod & Intra \\
\hline (Silva et al., 2009) & 2 & $\mathrm{n}-1$ & prod, distr & Inter \\
\hline (Frazzon et al., 2010) & 2 & $1-1$ & prod, distr & Inter \\
\hline (Gaudreault et al., 2010) & 3 & $1-1-1$ & prod & Intra \\
\hline (Gunnerud et al., 2010) & 1 & $\mathrm{n}$ & prod & Intra \\
\hline (Homberger, 2010) & $\mathrm{n}$ & $1-1-1$ & prod & Inter \\
\hline (Homberger et al., 2010) & $\mathrm{n}$ & $1-1-1$ & prod & Inter \\
\hline (Lee et al., 2010) & 2 & $1-n$ & distr & Inter \\
\hline (Lehoux et al., 2010a) & 2 & $1-1$ & prod, distr & Inter \\
\hline (Lehoux et al., 2010b) & 2 & $1-1$ & prod, distr & Inter \\
\hline (Homberger et al., 2011) & $\mathrm{n}$ & $1-1-1$ & prod & Inter \\
\hline (Homberger, 2011) & $\mathrm{n}$ & $1-1-1$ & prod & Inter \\
\hline (Lau et al., 2011) & 1 & $1-n$ & prod & Intra \\
\hline (Mouret et al., 2011) & 1 & $1-1$ & prod & Intra \\
\hline (Singh et al., 2011) & 2 & $1-n$ & prod & Inter \\
\hline (Lu et al., 2012) & 1 & $\mathrm{n}$ & - & - \\
\hline (Buer et al., 2013) & $\mathrm{n}$ & $1-1-1$ & prod & Inter \\
\hline (Kovács et al., 2013) & 2 & $1-1$ & prod & Inter \\
\hline (Taghipour et al., 2013) & 2 & $1-1$ & prod & Inter \\
\hline (Thomas et al., 2013) & 2 & $1-n$ & prod, distr & Inter \\
\hline (Ziebuhr et al., 2013) & $\mathrm{n}$ & $1-1-1$ & prod & Inter \\
\hline (Behnamian, 2014) & 2 & $\mathrm{n}-1$ & prod, distr & - \\
\hline (Kong et al., 2014) & 2 & $1-n$ & prod, distr & Intra \\
\hline (Lehoux et al., 2014) & 2 & $1-1$ & prod, distr & Inter \\
\hline (Reiss et al., 2014) & $\mathrm{n}$ & $1-1-1$ & prod & Inter \\
\hline (Sokoler et al., 2014) & 1 & $1-n$ & prod & - \\
\hline (Thomas et al., 2014) & 2 & $1-n$ & prod, distr & Inter \\
\hline (Acar et al., 2015) & 2 & $n-n$ & prod, distr & Intra \\
\hline (Albrecht et al., 2015) & 2 & $n-1$ & prod & - \\
\hline (Buer et al., 2015) & 2 & $\mathrm{n}-1$ & prod & Inter \\
\hline (Eslikizi et al., 2015) & 2 & $\mathrm{n}-1$ & prod & Inter \\
\hline (Harb et al., 2015) & 2 & $\mathrm{n}-1$ & prod & Inter \\
\hline (Homberger et al., 2015) & $\mathrm{n}$ & $1-1-1$ & prod & Inter \\
\hline (Mason et al., 2015) & 2 & $\mathrm{n}-1$ & prod & Inter \\
\hline (Qu et al., 2015) & 2 & $\mathrm{n}-1$ & prod & Inter \\
\hline (Thomas et al., 2015) & 2 & $1-n$ & prod, distr & Inter \\
\hline (Ziebuhr et al., 2015) & 2 & $\mathrm{n}-1$ & prod & Inter \\
\hline (Agnetis et al., 2016) & 2 & $1-1$ & prod, distr & Inter \\
\hline
\end{tabular}




\begin{tabular}{llll}
\hline (Bajgiran et al., 2016) & 3 & $1-n-n$ & prod, distr \\
(Jia et al., 2016) & 2 & $1-1$ & prod, distr \\
(Singh et al., 2016) & 2 & $n-1$ & prod \\
(Tang et al., 2016b) & 1 & $\mathrm{n}$ & prod \\
(Wenzel et al., 2016a) & 2 & $1-\mathrm{n}$ & prod \\
(Wenzel et al., 2016b) & 2 & $1-\mathrm{n}$ & prod \\
(Zoghlami et al., 2016) & 2 & $1-\mathrm{n}$ & prod \\
\hline
\end{tabular}

$n$ number of members, $n-n-n$ number of members on each tier level, prod production, distr distribution, - unknown

Of the papers, it can be highlighted the few works of intra-coordination. Therefore, there is an opportunity for works on the coordination within complex organizations where centralized solutions are not adequate, by their volume of information, maintenance of information or capacity to react on real time to changes. Within these works, it can be found several cases of complex petrochemical companies (Gunnerud et al., 2010; Mouret et al., 2011) or where real-time coordination of distributed control systems is sought (Cheng et al., 2008) or in the forest industry (Feng et al., 2008; Gaudreault et al., 2010; Pukkala et al., 2009). On the other hand, it can be seen in Table 6 the only three studies where the coordination with three SC levels (Bajgiran et al., 2016; Feng et al., 2008; Gaudreault et al., 2010) all of them from the wood industry (Table 8 ) .

The simplest collaboration is that established between two agents 1-1 (Jeong et al., 2009; Jia et al., 2016). But if it is wanted to delve deeper it is necessary to consider situations of several agents, 1-n, a supplier with several clients, which is a divergent SC (Dudek et al., 2007; Zoghlami et al., 2016) or n-1, several providers for a single client, which would be a considered a convergent one (Wenzel et al., 2016a, 2016b). But also intercompany cases, where there is no customer or supplier, identified as an $n$, in which it is necessary to coordinate among the agents, as in negotiation between workplace tasks for the fulfilment of orders as proposed by Ziebuhr et al. (2013), auctions between jobs for production scheduling (Tang et al., 2016b). And when several agents have to agree on how to share a common resource without the figure of a coordinator or mediator (Lu et al., 2012). Another step in the complexity, which brings us closer to the reality of the market, is when coordination must be established in situations n-n, several suppliers and clients that by auctions seek to coordinate resources (Dash et al., 2007), the supply chain as a network (Acar et al., 2015), in situations of shared SC such as in the clusters (Qu et al., 2015). And where manufacturing units must be coordinated with several logistics units (Pibernik et al., 2007). It can also be increased the complexity by considering more links in the SC, which is to say not only OEM with Tier 1, but also to include Tier 2 or Tier 0.5 or 3PL.

On the other hand, coordination proposals can refer to production problems, such as those related to the assignment of tasks, capacities or batches. But also, it can allude to coordination problems with distribution or sales (Feng et al., 2008). But such problems of coordination can also be between different business areas, such as production and distribution, such as the cases studied on the coordination of productive plants and their distribution service providers, the 3PL (Agnetis et al., 2016; Jia et al., 2016; Jung et al., 2008).

\subsection{Type of relationship between members of the SC}

In this section the type of relationship and behaviour of the agents are analysed. The need to generate trust to facilitate coordination (Manrodt et al., 2004), or the search for tools that allow to verify that the shared information is correct without any opportunism.

In analysing the power in the relationship, it was found that few works make explicit reference to it, if there are imbalances, on which side it is or if it is exerted. Therefore, the table has been completed based on the type of mechanism proposed and the ability to resolve discrepancies or left in blank. Power in 
coordination relationships has an important deterrent effect, in generating trust in collaborative relationships (Vitasek, 2016).

Regarding trust, in most of the works, teamwork behaviour has been assumed (see Table 7) except in the case of using auctions as a coordination tool (Dash et al., 2007) that implicitly corrects opportunistic behaviour. Although trust behaviours are not so unrealistic (Chen et al. 2004). However, there are few studies on the consequences of a possible opportunistic behaviour, although in several of them the need arises (Buer et al., 2013; Dash et al., 2007; Dudek et al., 2007; Lehoux et al., 2014; Pittman et al., 2007). In addition, when successive negotiations or exchanges of information between members are carried out, such non-essential information may allow an estimation of private or critical information, facilitating opportunistic positions. There are few studies that analyse or mention the learning of negotiation (Albrecht et al., 2015; Dash et al., 2007). Adequate incentives to provide true information on negotiation and influencing factors should be further addressed (Wang et al., 2016).

Another element is the rolling horizons, a common element in the industry to deal with uncertainty (Stadtler, 2007). In this process, the existing plan is updated and extended, involving the renegotiation of the effects of these changes with the SC members, but in most models it is not considered (Stadtler, 2007). In our selection of papers, only four studies have presented the rolling horizons (Frazzon et al., 2010; Lehoux et al., 2010a, 2010b, 2014) as a way of approaching the reality of industry, but without the renegotiation of the prejudices of the new plans.

Table 7 Relationships among SC members of reviewed works.

\begin{tabular}{|c|c|c|c|c|c|}
\hline Authors & Power & Behaviour & $\begin{array}{c}\text { Analysis of } \\
\text { team }\end{array}$ & $\begin{array}{c}\text { Learning } \\
\text { effect }\end{array}$ & $\begin{array}{l}\text { Rolling } \\
\text { horizon }\end{array}$ \\
\hline (Agnetis et al., 2006) & - & $\mathrm{T}$ & & & \\
\hline (Attanasio et al., 2006) & - & $\mathrm{T}$ & & & \\
\hline (Dash et al., 2007) & - & Oppor & $\mathrm{x}$ & $x$ & \\
\hline (Dudek et al., 2007) & S & $\mathrm{T}$ & $x$ & & \\
\hline (Pibernik et al., 2007) & - & $\mathrm{T}$ & $x$ & & \\
\hline (Pittman et al., 2007) & - & $\mathrm{T}$ & & & \\
\hline (Cheng et al., 2008) & - & $\mathrm{T}$ & & & \\
\hline (Feng et al., 2008) & - & $\mathrm{T}$ & & & \\
\hline (Jung et al., 2008) & B & $\mathrm{T}$ & & & \\
\hline (Kelly et al., 2008) & - & $\mathrm{T}$ & & & \\
\hline (Nie et al., 2008) & - & $\mathrm{T}$ & & & \\
\hline (Nishi et al., 2008) & S & $\mathrm{T}$ & & & \\
\hline (Walther et al., 2008) & B & $\mathrm{T}$ & & & \\
\hline (Jeong et al., 2009) & - & $\mathrm{T}$ & & & \\
\hline (Pukkala et al., 2009) & - & $\mathrm{T}$ & & & \\
\hline (Silva et al., 2009) & B & $\mathrm{T}$ & & & \\
\hline (Frazzon et al., 2010) & B & $\mathrm{T}$ & & & $\mathrm{x}$ \\
\hline (Gaudreault et al., 2010) & - & $\mathrm{T}$ & & & \\
\hline (Gunnerud et al., 2010) & - & $\mathrm{T}$ & & & \\
\hline (Homberger, 2010) & - & $\mathrm{T}$ & & & \\
\hline (Homberger et al., 2010) & - & $\mathrm{T}$ & & & \\
\hline (Lee et al., 2010) & S & $\mathrm{T}$ & & & \\
\hline (Lehoux et al., 2010a) & B & $\mathrm{T}$ & & & $x$ \\
\hline (Lehoux et al., 2010b) & B & $\mathrm{T}$ & & & $\mathrm{x}$ \\
\hline (Homberger et al., 2011) & - & $\mathrm{T}$ & & & \\
\hline (Homberger, 2011) & - & $\mathrm{T}$ & & & \\
\hline (Lau et al., 2011) & - & $\mathrm{T}$ & & & \\
\hline
\end{tabular}




\begin{tabular}{lll}
\hline (Mouret et al., 2011) & - & $\mathrm{T}$ \\
\hline (Singh et al., 2011) & $\mathrm{S}$ & $\mathrm{T}$ \\
\hline (Lu et al., 2012) & - & $\mathrm{T}$ \\
(Buer et al., 2013) & - & $\mathrm{T}$ \\
\hline (Kovács et al., 2013) & $\mathrm{B}$ & $\mathrm{T}$ \\
\hline (Taghipour et al., 2013) & $\mathrm{B}$ & $\mathrm{T}$ \\
(Thomas et al., 2013) & $\mathrm{S}$ & $\mathrm{T}$ \\
\hline (Ziebuhr et al., 2013) & - & $\mathrm{T}$ \\
(Behnamian, 2014) & - & $\mathrm{T}$ \\
\hline (Kong et al., 2014) & $\mathrm{S}$ & $\mathrm{T}$ \\
(Lehoux et al., 2014) & $\mathrm{B}$ & $\mathrm{T}$ \\
\hline (Reiss et al., 2014) & - & $\mathrm{T}$ \\
\hline (Sokoler et al., 2014) & - & $\mathrm{T}$ \\
\hline (Thomas et al., 2014) & $\mathrm{S}$ & $\mathrm{T}$ \\
\hline (Acar et al., 2015) & $\mathrm{B}$ & $\mathrm{T}$ \\
\hline (Albrecht et al., 2015) & $\mathrm{B}$ & $\mathrm{T}$ \\
\hline (Buer et al., 2015) & $\mathrm{B}$ & $\mathrm{T}$ \\
\hline (Eslikizi et al., 2015) & $\mathrm{B}$ & $\mathrm{T}$ \\
\hline (Harb et al., 2015) & $\mathrm{B}$ & $\mathrm{T}$ \\
\hline (Homberger et al., 2015) & - & $\mathrm{T}$ \\
\hline (Mason et al., 2015) & $\mathrm{B}$ & $\mathrm{T}$ \\
\hline (Qu et al., 2015) & $\mathrm{B}$ & $\mathrm{T}$ \\
\hline (Thomas et al., 2015) & $\mathrm{S}$ & $\mathrm{T}$ \\
\hline (Ziebuhr et al., 2015) & $\mathrm{B}$ & $\mathrm{T}$ \\
\hline (Agnetis et al., 2016) & $\mathrm{B}$ & $\mathrm{T}$ \\
\hline (Bajgiran et al., 2016) & $\mathrm{B}$ & $\mathrm{T}$ \\
\hline (Jia et al., 2016) & $\mathrm{B}$ & $\mathrm{T}$ \\
\hline (Singh et al., 2016) & $\mathrm{B}$ & $\mathrm{T}$ \\
\hline (Tang et al., 2016b) & - & $\mathrm{T}$ \\
\hline (Wenzel et al., 2016a) & $\mathrm{S}$ & $\mathrm{T}$ \\
(Wenzel et al., 2016b) & $\mathrm{S}$ & $\mathrm{T}$ \\
\hline (Zoghlami et al., 2016) & $\mathrm{B}$ & $\mathrm{T}$ \\
\hline B buyer $S$ supplier, T team $O p p o r$ opportunism & & \\
\hline & & \\
\hline
\end{tabular}

$B$ buyer, $S$ supplier, T team, Oppor opportunism

\subsection{Objectives of coordination mechanism}

In this section it is highlighted the pretensions of the coordination mechanisms (see Table 8). In cases where a centralized coordination with all the information is feasible, it will be able to find a better solution to planning problems (Pibernik et al., 2007), even more so in cases of uncertainty (Acar et al., 2015). However, coordination mechanisms may simply seek to improve against non-coordination. For example, hierarchical coordination mechanisms without compensations or renegotiations, both upstream and downstream, achieve better alignment of flows (material) in the SC and improve against noncoordination (Agnetis et al., 2016), "alignment" in Table 8. On the other hand, other mechanisms seek to get closer to the optimal global results, knowing that it may incur worse local results of some of its members that must compensate with compensations or discounts (Eslikizi et al., 2015), "near opt." in Table 8 . It is found that $49 \%$ of the included paper tries to find an optimal solution, even when a culture of team behaviour is not necessarily common in the industry, and is required in almost all mechanism. In other cases, it simply seeks a rightful solution that does not necessarily seek the global optimum but a fair distribution (Lehoux et al., 2010a), "fair" in Table 8. Different definitions of the term "fair" can be found in Stadtler (2007) or Katok \& Pavlov (2013).

Table 8 Required solution, results and sector of reviewed works.

\begin{tabular}{llll}
\hline Authors & $\begin{array}{l}\text { Required SC } \\
\text { solution }\end{array}$ & $\begin{array}{l}\text { Final results } \\
\text { quality }\end{array}$ & Sector \\
\hline
\end{tabular}




\begin{tabular}{|c|c|c|c|}
\hline (Agnetis et al., 2006) & alignment & proof & - \\
\hline (Attanasio et al., 2006) & near opt. & computer & Computational grid \\
\hline (Dash et al., 2007) & near opt. & computer & - \\
\hline (Dudek et al., 2007) & fair & computer & - \\
\hline (Pibernik et al., 2007) & fair & computer & - \\
\hline (Pittman et al., 2007) & near opt. & simulation & Wood industry \\
\hline (Cheng et al., 2008) & near opt. & simulation & Chemical industry \\
\hline (Feng et al., 2008) & alignment & simulation & Wood industry \\
\hline (Jung et al., 2008) & alignment & computer & $3 \mathrm{PL}$ \\
\hline (Kelly et al., 2008) & alignment & simulation & Chemical industry \\
\hline (Nie et al., 2008) & near opt. & computer & - \\
\hline (Nishi et al., 2008) & near opt. & simulation & Chemical industry \\
\hline (Walther et al., 2008) & near opt. & simulation & Recycling industry \\
\hline (Jeong et al., 2009) & near opt. & computer & - \\
\hline (Pukkala et al., 2009) & near opt. & simulation & Wood industry \\
\hline (Silva et al., 2009) & alignment & simulation & - \\
\hline (Frazzon et al., 2010) & alignment & simulation & 3PL \\
\hline (Gaudreault et al., 2010) & alignment & simulation & Wood industry \\
\hline (Gunnerud et al., 2010) & near opt. & simulation & Chemical industry \\
\hline (Homberger, 2010) & fair & computer & $*$ \\
\hline (Homberger et al., 2010) & fair & computer & $*$ \\
\hline (Lee et al., 2010) & near opt. & computer & - \\
\hline (Lehoux et al., 2010a) & fair & simulation & Wood industry \\
\hline (Lehoux et al., 2010b) & fair & simulation & Wood industry \\
\hline (Homberger et al., 2011) & fair & computer & * \\
\hline (Homberger, 2011) & fair & computer & $*$ \\
\hline (Lau et al., 2011) & near opt. & simulation & Container Terminal Operations \\
\hline (Mouret et al., 2011) & near opt. & simulation & Chemical industry \\
\hline (Singh et al., 2011) & near opt. & computer & Mining industry \\
\hline (Lu et al., 2012) & near opt. & computer, proof & - \\
\hline (Buer et al., 2013) & fair & computer & $*$ \\
\hline (Kovács et al., 2013) & fair & computer & - \\
\hline (Taghipour et al., 2013) & fair & computer & - \\
\hline (Thomas et al., 2013) & near opt. & computer & Mining industry \\
\hline (Ziebuhr et al., 2013) & fair & computer & $*$ \\
\hline (Behnamian, 2014) & near opt. & computer & - \\
\hline (Kong et al., 2014) & near opt. & simulation & Wood industry \\
\hline (Lehoux et al., 2014) & fair & simulation & Wood industry \\
\hline (Reiss et al., 2014) & alignment & computer & $*$ \\
\hline (Sokoler et al., 2014) & near opt. & simulation & Energy industry \\
\hline (Thomas et al., 2014) & near opt. & computer & Mining industry \\
\hline (Acar et al., 2015) & alignment & simulation & Chemical industry \\
\hline (Albrecht et al., 2015) & near opt. & proof & - \\
\hline (Buer et al., 2015) & fair & computer & $*$ \\
\hline (Eslikizi et al., 2015) & fair & computer & $*$ \\
\hline (Harb et al., 2015) & near opt. & simulation & Heating industry \\
\hline (Homberger et al., 2015) & fair & computer & $*$ \\
\hline (Mason et al., 2015) & near opt. & simulation & Farm industry \\
\hline (Qu et al., 2015) & near opt. & simulation & - \\
\hline (Thomas et al., 2015) & near opt. & computer & Mining industry \\
\hline (Ziebuhr et al., 2015) & fair & computer & $*$ \\
\hline (Agnetis et al., 2016) & fair & computer & 3PL \\
\hline (Bajgiran et al., 2016) & near opt. & simulation & Wood industry \\
\hline
\end{tabular}




\begin{tabular}{|c|c|c|c|}
\hline (Jia et al., 2016) & fair & computer & $3 \mathrm{PL}$ \\
\hline (Singh et al., 2016) & near opt. & computer & - \\
\hline (Tang et al., 2016b) & fair & computer & - \\
\hline (Wenzel et al., 2016a) & near opt. & simulation & Chemical industry \\
\hline (Wenzel et al., 2016b) & near opt. & simulation & Chemical industry \\
\hline (Zoghlami et al., 2016) & fair & computer & - \\
\hline
\end{tabular}

\subsection{Models in collaboration}

In this section, it is tried to analyse the modelling approach used (see Table 9). Most use linear programming modelling approach with binary or integer elements (MILP Mixed Integer Linear Programming), except four which are linear (LP) programming. On the other hand, four apply quadratic programming (QP). Finally, quasi-linear to be able to apply the mechanisms of Vickrey-Clarke-Groves (VCG) (Dash et al., 2007).

The phase in which co-ordination arises is in most cases in its planning phase, when assigning orders or loads or lots to agents. Only in four, it is in the design phase, when determining interlocutors and capacities. The remainder are in the execution phase, when sequencing is set and loads were already assigned. On the other hand, it has not been found that it is used in the evaluation phase of past situations that could serve for future negotiations, as Stadtler (2007) said.

Regarding which information is hidden and which is shared, it is necessary to emphasize that it is usual to hide the local costs, since each agent is allowed to make its own calculations locally and only the internal price is shared by the shared resource, with the use of this resource or the acceptance of different planning proposals. It is important to emphasize the need for a security protocol to share only the aggregate of the use of shared capacity, leaving behind in that protocol the detailed use of resources (Singh et al., 2016).

Table 9 Models and steps of reviewed works.

\begin{tabular}{|c|c|c|c|c|c|c|}
\hline Authors & $\begin{array}{l}\text { Decision } \\
\text { modelling }\end{array}$ & $\begin{array}{l}\text { Phase of } \\
\text { collaboration }\end{array}$ & $\begin{array}{l}\text { Hidden } \\
\text { information }\end{array}$ & Exchanged information & $\begin{array}{l}\text { Global } \\
\text { Objectives }\end{array}$ & $\begin{array}{l}\text { Local } \\
\text { Objectives }\end{array}$ \\
\hline (Agnetis et al., 2006) & MILP & Execution & local costs & $\begin{array}{l}\text { schedule, buffer capacity, } \\
\text { storage cost }\end{array}$ & $\mathrm{MC}$ & $\mathrm{MC}$ \\
\hline (Attanasio et al., 2006) & MILP & Execution & local capacity & resource dual value & MCman & MCman \\
\hline (Dash et al., 2007) & $\begin{array}{l}\text { auction / } \\
\text { Quasi-linear }\end{array}$ & Planning & local costs & Quantity, price & MRA & MP \\
\hline (Dudek et al., 2007) & MILP & Planning & local costs & $\begin{array}{l}\text { differential cost form their } \\
\text { optimal value }\end{array}$ & $\mathrm{MC}$ & $\mathrm{MC}$ \\
\hline (Pibernik et al., 2007) & MILP & Planning & local costs & demand & $\mathrm{MC}$ & $\mathrm{MC}$ \\
\hline (Pittman et al., 2007) & MILP & Planning & $\begin{array}{l}\text { local harvest } \\
\text { restriction }\end{array}$ & internal price & MNPV & MNPV \\
\hline (Cheng et al., 2008) & LP & Execution & $\begin{array}{l}\text { local chemical } \\
\text { parameters }\end{array}$ & $\begin{array}{l}\text { internal price for shared } \\
\text { steam }\end{array}$ & $\mathrm{MC}$ & $\mathrm{MC}$ \\
\hline (Feng et al., 2008) & MILP & Planning & local cost & sales, lot size & MP & MC \\
\hline (Jung et al., 2008) & LP & Execution & local costs & preferred plan & $\mathrm{MC}$ & $\mathrm{MC}$ \\
\hline (Kelly et al., 2008) & MILP & Execution & $\begin{array}{l}\text { local } \\
\text { restriction }\end{array}$ & $\begin{array}{l}\text { resource, regulation, } \\
\text { register, offers and } \\
\text { obstacles-offsets-outages }\end{array}$ & $\mathrm{MC}$ & $\mathrm{MC}$ \\
\hline (Nie et al., 2008) & MILP & Planning & local costs & internal price & $\mathrm{MC}$ & $\mathrm{MC}$ \\
\hline (Nishi et al., 2008) & MILP & Planning & local costs & internal price & $\mathrm{MC}$ & $\mathrm{MC}$ \\
\hline (Walther et al., 2008) & MILP & Planning & local costs & internal price & MP & MP \\
\hline (Jeong et al., 2009) & MILP & Execution & $\begin{array}{l}\text { processing } \\
\text { time and } \\
\text { routings on }\end{array}$ & machine use & MTCi & MTCi \\
\hline
\end{tabular}




\begin{tabular}{|c|c|c|c|c|c|c|}
\hline (Pukkala et al., 2009) & MILP & Planning & $\begin{array}{l}\text { local grow } \\
\text { conditions }\end{array}$ & internal price & MFG & MFG \\
\hline (Silva et al., 2009) & MILP & Execution & local costs & pheromone matrix & $\mathrm{MC}$ & $\mathrm{MC}$ \\
\hline (Frazzon et al., 2010) & MILP & Execution & local cost & $\begin{array}{l}\text { provision date of orders, } \\
\text { demand }\end{array}$ & $\mathrm{MC}$ & $\mathrm{MC}$ \\
\hline $\begin{array}{l}\text { (Gaudreault et al., } \\
\text { 2010) }\end{array}$ & MILP & Planning & local costs & demand & $\mathrm{MC}$ & $\mathrm{MC}$ \\
\hline (Gunnerud et al., 2010) & MILP & Execution & local costs & internal price & $\mathrm{MC}$ & $\mathrm{MC}$ \\
\hline (Homberger, 2010) & MILP & Planning & local costs & $\begin{array}{l}\text { proposed contracts and } \\
\text { agents votes }\end{array}$ & MV & $\mathrm{MC}$ \\
\hline $\begin{array}{l}\text { (Homberger et al., } \\
\text { 2010) }\end{array}$ & MILP & Planning & local costs & $\begin{array}{l}\text { proposed contracts and } \\
\text { agents votes }\end{array}$ & MV & $\mathrm{MC}$ \\
\hline (Lee et al., 2010) & MILP & Planning & local costs & $\begin{array}{l}\text { order periods, demand, } \\
\text { warehouse cost/orders } \\
\text { periods }\end{array}$ & $\mathrm{MC}$ & $\mathrm{MC}$ \\
\hline (Lehoux et al., 2010a) & MILP & Planning & local costs & orders & MP & MP \\
\hline (Lehoux et al., 2010b) & MILP & Planning & local costs & orders/inventory cost & MP & MP \\
\hline $\begin{array}{l}\text { (Homberger et al., } \\
\text { 2011) }\end{array}$ & MILP & Planning & local costs & $\begin{array}{l}\text { proposed contracts and } \\
\text { agents votes }\end{array}$ & MV & $\mathrm{MC}$ \\
\hline (Homberger, 2011) & MILP & Planning & local costs & $\begin{array}{l}\text { proposed contracts and } \\
\text { agents votes }\end{array}$ & MV & $\mathrm{MC}$ \\
\hline (Lau et al., 2011) & MILP & Execution & local capacity & internal price & MCman & MCman \\
\hline (Mouret et al., 2011) & MILP & Execution & local costs & internal price & MP & MP \\
\hline (Singh et al., 2011) & MILP & Execution & $\begin{array}{l}\text { local } \\
\text { requirements }\end{array}$ & internal price & MTWT & MTWT \\
\hline (Lu et al., 2012) & LP & Planning & local costs & $\begin{array}{l}\text { use of common resources } \\
\text { and internal prices }\end{array}$ & MP & MP \\
\hline (Buer et al., 2013) & MILP & Planning & local costs & $\begin{array}{l}\text { proposed contracts and } \\
\text { agents votes }\end{array}$ & MV & $\mathrm{MC}$ \\
\hline (Kovács et al., 2013) & MILP & Planning & local costs & $\begin{array}{l}\text { proposal contract interest } \\
\text { and financial incentives, }\end{array}$ & MP & MP \\
\hline (Taghipour et al., 2013) & MILP & Planning & local costs & $\begin{array}{l}\text { proposal contract interest } \\
\text { and financial incentives, }\end{array}$ & MP & MP \\
\hline (Thomas et al., 2013) & MILP & Planning & local costs & internal price & $\mathrm{MC}$ & $\mathrm{MC}$ \\
\hline (Ziebuhr et al., 2013) & MILP & Planning & local costs & $\begin{array}{l}\text { proposed contracts and } \\
\text { agents votes }\end{array}$ & MV & $\mathrm{MC}$ \\
\hline (Behnamian, 2014) & MILP & Planning & local capacity & feasibility & $\mathrm{MC}$ & Due date \\
\hline (Kong et al., 2014) & MILP & Planning & local costs & internal price & MP & MP \\
\hline (Lehoux et al., 2014) & MILP & Planning & local costs & demand & MP & MP \\
\hline (Reiss et al., 2014) & MILP & Planning & local costs & $\begin{array}{l}\text { proposed contracts and } \\
\text { agents variation of the local } \\
\text { production cost }\end{array}$ & $\mathrm{MC}$ & $\mathrm{MC}$ \\
\hline (Sokoler et al., 2014) & LP - QP & Planning & local costs & internal price & $\mathrm{MC}$ & $\mathrm{MC}$ \\
\hline (Thomas et al., 2014) & MILP & Planning & local costs & internal price & $\mathrm{MC}$ & MTWT \\
\hline (Acar et al., 2015) & MILP & Planning & local plan & demand, cost, capacity & $\mathrm{MC}$ & $\mathrm{MC}$ \\
\hline (Albrecht et al., 2015) & LP & Planning & local costs & $\begin{array}{l}\text { assignments and cost } \\
\text { differential }\end{array}$ & MP & MP \\
\hline (Buer et al., 2015) & MILP & $\begin{array}{l}\text { Design/Plann } \\
\text { ing }\end{array}$ & $\begin{array}{l}\text { local set up } \\
\text { and inventory } \\
\text { holding }\end{array}$ & $\begin{array}{l}\text { proposed contracts, agents } \\
\text { votes, local total cost and } \\
\text { savings }\end{array}$ & MV & $\mathrm{MC}$ \\
\hline (Eslikizi et al., 2015) & MILP & $\begin{array}{l}\text { Design/Plann } \\
\text { ing }\end{array}$ & $\begin{array}{l}\text { local set up } \\
\text { and inventory } \\
\text { holding }\end{array}$ & $\begin{array}{l}\text { proposed contracts, agents } \\
\text { votes, local total cost and } \\
\text { savings }\end{array}$ & MV & $\mathrm{MC}$ \\
\hline (Harb et al., 2015) & MILP & Planning & local costs & internal price & $\mathrm{MC}$ & $\mathrm{MC}$ \\
\hline $\begin{array}{l}\text { (Homberger et al., } \\
\text { 2015) }\end{array}$ & MILP & Planning & local costs & $\begin{array}{l}\text { proposed contracts, agent } \\
\text { voting and agents variation } \\
\text { of the local production cost }\end{array}$ & MV & $\mathrm{MC}$ \\
\hline (Mason et al., 2015) & MILP & Planning & local costs & internal price & MP & MP \\
\hline (Qu et al., 2015) & $\mathrm{QP}$ & Design/Plann & local costs & internal price & MP & MP \\
\hline
\end{tabular}




\begin{tabular}{|c|c|c|c|c|c|c|}
\hline & & ing & & & & \\
\hline (Thomas et al., 2015) & MILP & Planning & local costs & $\begin{array}{l}\text { internal price and resource } \\
\text { availability or production } \\
\text { capacity }\end{array}$ & $\mathrm{MC}$ & $\mathrm{MC}$ \\
\hline (Ziebuhr et al., 2015) & MILP & $\begin{array}{l}\text { Design/Plann } \\
\text { ing }\end{array}$ & local costs & $\begin{array}{l}\text { proposed contracts, agents } \\
\text { votes }\end{array}$ & MV & $\mathrm{MC}$ \\
\hline (Agnetis et al., 2016) & MILP & Execution & $\begin{array}{l}\text { local cost, } \\
\text { capacities }\end{array}$ & $\begin{array}{l}\text { due dates, planning } \\
\text { proposed }\end{array}$ & MCman & $\begin{array}{l}\mathrm{MC} \\
\text { Mcman }\end{array}$ \\
\hline (Bajgiran et al., 2016) & MILP & Planning & local costs & internal price & MP & $\mathrm{MC}$ \\
\hline (Jia et al., 2016) & MILP & Planning & $\begin{array}{l}\text { local cost, } \\
\text { capacities }\end{array}$ & $\begin{array}{l}\text { planning proposed and } \\
\text { compensation }\end{array}$ & MP & MP \\
\hline (Singh et al., 2016) & MILP & Planning & local costs & internal price & $\mathrm{MC}$ & $\mathrm{MC}$ \\
\hline (Tang et al., 2016b) & MILP & Execution & capacities & internal price & MCman & MCman \\
\hline (Wenzel et al., 2016a) & QP & Planning & local costs & internal price & $\mathrm{MC}$ & $\mathrm{MC}$ \\
\hline (Wenzel et al., 2016b) & QP & Planning & local costs & internal price & $\mathrm{MC}$ & $\mathrm{MC}$ \\
\hline (Zoghlami et al., 2016) & MILP & Planning & local costs & $\begin{array}{l}\text { proposed contract interest } \\
\text { and discount incentives }\end{array}$ & MP & MP \\
\hline
\end{tabular}

MILP Mixed Integer Linear Programming, LP Linear Programming, $Q P$ Quadratic Programming, $M C$ Minimize cost, $M C$ man Minimize makespan, MRA Maximize resource allocation, MP Maximize profit, $M T C i$ Minimize total completion time, $M F G$ Maximize forest grow, $M V$ Maximize voting, $M N P V$ Maximize net present value of income, $M T W T$ Minimize total weighted tardiness

\subsection{Characteristics of the implementation of the mechanism}

In this section, it is analysed the coordination mechanisms used. Of these, it can be highlighted that 20 works have used the Lagrange multiplier (Table 10). It has been considered separately the DW method and Benders although they are an extension of the Lagrange multiplier.

From the work with the Lagrangian multiplier it can be seen that the heuristic of the subgradient (Fisher, 1985; Held et al., 1970, 1971) is used to update the multiplier in seven of the works (Attanasio et al., 2006; Jeong et al., 2009; Kong et al., 2014; Lau et al., 2011; Lu et al., 2012; Pukkala et al., 2009; Walther et al., 2008). As Fisher (2004) comments, the method does not meet the convergence requirement, that the sum of gradients tends to infinity, but it works empirically. But the subgradient method tends to oscillate in its outcome (Singh et al., 2011) and its convergence speed (Nie et al., 2008) especially when the size of the passage is small (Thomas et al., 2013). The multiplier has also been updated, using the Augmented Lagrangian method, a quadratic function to update the multiplier (Table 10). This quadratic function can be linearized to maintain the linear modelling approach (Nishi et al., 2008) or to maintain a nonlinear modelling approach (Qu et al., 2015) or work with a quadratic function (Lee et al., 2010; Wenzel et al., 2016a, 2016b). Another method of updating the multiplier is by Volume Algorithm (Singh et al., 2011, 2016) and its combination with Wedelin Algorithms (Thomas et al., 2015, 2013). Other alternatives are the mixture of cutting plans, subgradient and boxstep applied by Mouret et al. (2011). Also in combining it with meta-heuristics such as Genetic Algorithm (Nie et al., 2008) or immunological system (Lu et al., 2012) or specific problem heuristics (Bajgiran et al., 2016). Another line is the update of the Lagrange multiplier by Column Generation (Sokoler et al., 2014) or stabilized by weighted elements proposed by Thomas et al. (2014).

Another tool used is the Lagrange decomposition by the Dantzig-Wolfe method (1960) that it is found in seven works (Table 10). In this work, the internal price of the use of the shared resource or shadow price is updated by the centralized mediator (Harb et al., 2015; Mason et al., 2015), who seeks to meet relaxed restrictions by adjusting the price, by raising resource prices when agents request more resources. This method tends to the optimal solution of the system as the Lagrange multiplier update in linear modelling approach by the subgradient (Polyak 1969). 
Equivalent is the method proposed by the decomposition of Benders (1962). Benders proposes to dualize the function and then relax the constraints to generate separable sub-problems or agents, where a centralized problem must add the optima of each sub-problem with constraints and functions that cannot be decomposed. The Bender method will request the prices proposed by the agents to reduce or increase the shares (Behnamian, 2014).

Another alternative of a coordinating mechanism has been meta-heuristics, such as ant colony or pheromone (Silva et al., 2009) or Simulated Annealing (Buer et al., 2015; Dudek et al., 2007; Eslikizi et al., 2015; Ziebuhr et al., 2013, 2015) or variable neighbourhood search (Reiss et al., 2014) that allow to seek a better coordination according to pre-established rules but without guarantees of being optimal.

Other works have sought that the agents vote or bid for the best combination according to their local interests. By extending Vickrey-Clarke-Groves (VCG) to a Continuous Double Auction (CDA) so that agents are encouraged to honestly report their capabilities and costs for potential penalties (Dash et al., 2007). In other cases, with a finite solutions modelling approach (Distributed Multi-Level Uncapacitated Lot-Sizing Problem)(DMLULSP) they are voted and applied meta-heuristic neighbourhood search (Homberger et al., 2015) to find a better solution. These votes have also been evaluated by rules Borda maximum voting rule along with meta-heuristics ant colony or pheromone (Homberger et al., 2011, 2010) or evolutionary algorithms (Homberger, 2011), or with other voting rules Metropolis acceptance criterion and the meta-heuristic simulated annealing (Homberger, 2010) or with different rules Rawls or min-max voting rule and the meta-heuristic ant colony or pheromone (Buer et al., 2013). Also auctions using modelling approach of nonlinear mathematical programming (Tang et al., 2016b). Another example is a combinatorial auction of the machine allocation problem that adjusts the allocation price with the subgradient method (Lau et al., 2011).

In addition, there are hierarchical mechanisms, where the needs are reported. This simple method gives better results than disinformation or non-coordination, where suppliers must make forecasts of demand according to historical or other data. The hierarchical coordination mechanism can be initiated by propositions without downstream negotiations (Acar et al., 2015), upstream (Agnetis et al., 2006; Frazzon et al., 2010), with counter-proposals (Gaudreault et al., 2010), with negotiations (Kelly et al., 2008) and with compensations (Taghipour et al., 2013). Although the effects of local decisions of all partners are not taken into account, suboptimal plans can be produced in comparison to centralized coordination (Bhatnagar et al., 1993). Dudek (2005) compared upstream planning with centralized planning, observing average differences of $14.1 \%$ in total SC costs.

Finally, other methods of coordination have been compared, such as the CFPR (collaborative planning, forecasting and replenishment) (VICS, 2004) proposals, assimilating it to a forecast of shared demand, or VMI (Vendor Management Inventory), or RR (regular replenishment) (Lehoux et al., 2010b).

On the other hand, it is necessary to emphasize that, if it is wanted to achieve the compensation of the local optimum among the agents and reach better global solutions close to the centralized optimal solution, it is necessary to contemplate the compensations or the discounts between agents. It can be identified the twelve jobs with side-payments in Table 10.

Lastly, several works have proposed coordination mechanism without the need for a mediator. Of which it can be highlighted three, that without the figure of a mediator, try to reach results close to the global optimums (Albrecht et al., 2015; Lee et al., 2010; Lu et al., 2012), although they lack its application in real cases. The others are hierarchical processes and in some cases compensations are made that allow fairer results (Jia et al., 2016; Kovács et al., 2013; Lehoux et al., 2010a, 2014; Pibernik et al., 2007; Silva et al., 2009; Taghipour et al., 2013; Zoghlami et al., 2016) 
Table 10 Coordination mechanism of reviewed works

\begin{tabular}{|c|c|c|c|c|c|c|c|}
\hline Authors & & Mechanism & & $\begin{array}{r}\text { Initial } \\
\text { solution }\end{array}$ & $\begin{array}{l}N^{\circ} \text { of plans } \\
\text { exchanged }\end{array}$ & $\begin{array}{c}\text { Side } \\
\text { payments }\end{array}$ & $\begin{array}{l}\text { Negotiation } \\
\text { Stopping } \\
\text { Criteria }\end{array}$ \\
\hline (Agnetis et al., 2006) & HBP & Hierarchical, no negotiation & & $\mathrm{D}$ & 1 & & - \\
\hline (Attanasio et al., 2006) & $\mathrm{AN}$ & Auction, Lagrangian-based decomposition & $\mathrm{x}$ & $\mathrm{D}$ & big & & IN or MG \\
\hline (Dash et al., 2007) & $\mathrm{AM}$ & Continuous Double Auction & & $\mathrm{D}$ & big & & DA \\
\hline (Dudek et al., 2007) & MH & $\begin{array}{l}\text { Shared cost increase and Simulated } \\
\text { Annealing }\end{array}$ & & $\mathrm{U}$ & small & $\mathrm{x}$ & $\mathrm{SA}$ \\
\hline (Pibernik et al., 2007) & HBP & $\begin{array}{l}\text { Partially centralized with a hierarchical } \\
\text { without negotiation }\end{array}$ & & $\mathrm{U}$ & 1 & $\mathrm{x}$ & - \\
\hline (Pittman et al., 2007) & DW & Dantzig-Wolfe decomposition & $\mathrm{x}$ & $\mathrm{L}$ & big & & $\mathrm{IN}$ or $\mathrm{MG}$ \\
\hline (Cheng et al., 2008) & DW & Dantzig-Wolfe decomposition & $\mathrm{x}$ & $\mathrm{L}$ & big & & $\mathrm{IN}$ or $\mathrm{MG}$ \\
\hline (Feng et al., 2008) & HBP & Hierarchical, no negotiation & & $\mathrm{D}$ & 1 & & - \\
\hline (Jung et al., 2008) & HBP & Hierarchical, negotiation & & $\mathrm{D}$ & small & & $\mathrm{DA}$ \\
\hline (Kelly et al., 2008) & HBP & Hierarchical, weight adjustment & & $\mathrm{D}$ & small & & $\mathrm{CT}$ \\
\hline (Nie et al., 2008) & LR & $\begin{array}{l}\text { Lagrangian relaxation and multiplier } \\
\text { update with Genetic Algorithms }\end{array}$ & $\mathrm{x}$ & $\mathrm{D}$ & big & & IN or $\mathrm{MG}$ \\
\hline (Nishi et al., 2008) & LR & Augmented Lagrangian linearized & $\mathrm{x}$ & $\mathrm{L}$ & big & & IN or $\mathrm{MG}$ \\
\hline (Walther et al., 2008) & LR & $\begin{array}{l}\text { Lagrangian relaxation and multiplier } \\
\text { update with a linear function }\end{array}$ & $\mathrm{x}$ & $\mathrm{U}$ & big & & IN or $\mathrm{MG}$ \\
\hline (Jeong et al., 2009) & LR & $\begin{array}{l}\text { Lagrangian relaxation and multiplier } \\
\text { update with modified subgradient }\end{array}$ & $\mathrm{x}$ & $\mathrm{L}$ & big & & IN or $\mathrm{MG}$ \\
\hline (Pukkala et al., 2009) & LR & Lagrangian relaxation, subgradient & $\mathrm{x}$ & $\mathrm{L}$ & big & & IN \\
\hline (Silva et al., 2009) & MH & Pheromone matrix & & $\mathrm{D}$ & small & & IN \\
\hline (Frazzon et al., 2010) & HBP & Hierarchical, no negotiation & & $\mathrm{U}$ & 1 & & - \\
\hline $\begin{array}{l}\text { (Gaudreault et al., } \\
\text { 2010) }\end{array}$ & HBP & Hierarchical, negotiation & & $\mathrm{B}$ & 2 & & - \\
\hline (Gunnerud et al., 2010) & $\begin{array}{l}\text { DW/ } \\
\text { LR }\end{array}$ & DW, Lagrangian decomposition & $\mathrm{x}$ & $\mathrm{L}$ & small & & MG \\
\hline (Homberger, 2010) & $\mathrm{MH}$ & $\begin{array}{l}\text { Metropolis acceptance criterion and } \\
\text { Simulated annealing method }\end{array}$ & $\mathrm{x}$ & $\mathrm{R}$ & big & & SA \\
\hline $\begin{array}{l}\text { (Homberger et al., } \\
\text { 2010) }\end{array}$ & $\mathrm{MH}$ & $\begin{array}{l}\text { Borda maxmin voting rule and } \\
\text { Pheromone matrix }\end{array}$ & $\mathrm{x}$ & $\mathrm{R}$ & big & & $\mathrm{IN}$ \\
\hline (Lee et al., 2010) & LR & $\begin{array}{l}\text { Augmented Lagrangian with Alternating } \\
\text { Direction Method and Diagonal Quadratic } \\
\text { Approximation Method }\end{array}$ & $\mathrm{x}$ & $\mathrm{L}$ & big & & $\mathrm{IN}$ \\
\hline (Lehoux et al., 2010a) & HBP & Hierarchical, no negotiation & & D & 1 & $\mathrm{x}$ & - \\
\hline (Lehoux et al., 2010b) & HBP & Vendor Managed Inventory & & $\mathrm{D}$ & 1 & & - \\
\hline $\begin{array}{l}\text { (Homberger et al., } \\
\text { 2011) }\end{array}$ & $\mathrm{MH}$ & $\begin{array}{l}\text { Borda maxmin voting rule and } \\
\text { Pheromone matrix }\end{array}$ & $\mathrm{x}$ & $\mathrm{R}$ & big & & IN \\
\hline (Homberger, 2011) & $\mathrm{MH}$ & $\begin{array}{l}\text { Borda maxmin voting rule and } \\
\text { Evolutionary Algorithms }\end{array}$ & $\mathrm{x}$ & $\mathrm{R}$ & big & & $\mathrm{IN}$ \\
\hline (Lau et al., 2011) & $\mathrm{AM}$ & $\begin{array}{l}\text { Combinatorial auction - Lagrangian } \\
\text { relaxation }\end{array}$ & $\mathrm{x}$ & $\mathrm{U}$ & small & & IN \\
\hline (Mouret et al., 2011) & LR & $\begin{array}{l}\text { Lagrangian decomposition, multiplier is } \\
\text { updated with cutting planes, subgradient, } \\
\text { and boxstep }\end{array}$ & $\mathrm{x}$ & $\mathrm{D}$ & small & & $\mathrm{IN}$ or $\mathrm{MG}$ \\
\hline (Singh et al., 2011) & LR & $\begin{array}{l}\text { Lagrangian relaxation, multiplier is } \\
\text { updated with Volume Algorithm }\end{array}$ & $\mathrm{x}$ & $\mathrm{D}$ & big & & IN or $\mathrm{MG}$ \\
\hline (Lu et al., 2012) & LR & $\begin{array}{l}\text { Lagrangian relaxation and immunity- } \\
\text { inspired coordination (LR-ICI) }\end{array}$ & & $\mathrm{L}$ & big & & IN or $\mathrm{MG}$ \\
\hline (Buer et al., 2013) & $\mathrm{MH}$ & $\begin{array}{l}\text { Modification of Borda maxmin voting } \\
\text { rule and Pheromone matrix }\end{array}$ & $\mathrm{x}$ & $\mathrm{R}$ & big & & IN \\
\hline (Kovács et al., 2013) & HBP & Hierarchical, shared benefits & & $\mathrm{D}$ & small & $\mathrm{x}$ & $2^{\circ}$ \\
\hline (Taghipour et al., 2013) & HBP & Hierarchical, shared discount & & $\mathrm{D}$ & small & $\mathrm{x}$ & $2^{\circ}$ \\
\hline (Thomas et al., 2013) & LR & $\begin{array}{l}\text { Lagrangian relaxation, with Volume and } \\
\text { Wedelin Algorithms. }\end{array}$ & $\mathrm{x}$ & $\mathrm{U}$ & big & & CTor MG \\
\hline
\end{tabular}




\begin{tabular}{|c|c|c|c|c|c|c|c|}
\hline (Ziebuhr et al., 2013) & $\mathrm{MH}$ & $\begin{array}{l}\text { Metropolis acceptance criterion and } \\
\text { Simulated annealing method extended by } \\
\text { a part-way reset procedure }\end{array}$ & $\mathrm{x}$ & $\mathrm{R}$ & big & & SA \\
\hline (Behnamian, 2014) & $\mathrm{B}$ & Benders decomposition & $\mathrm{x}$ & $\mathrm{D}$ & big & & $\begin{array}{l}\text { CT or } \\
\text { feasible }\end{array}$ \\
\hline (Kong et al., 2014) & LR & Lagrangian decomposition, subgradient & $\mathrm{x}$ & $\mathrm{D}$ & big & & $\mathrm{CT}$ or MG \\
\hline (Lehoux et al., 2014) & HBP & Hierarchical, shared benefits & & $\mathrm{D}$ & 1 & $\mathrm{x}$ & - \\
\hline (Reiss et al., 2014) & $\mathrm{MH}$ & $\begin{array}{l}\text { Increases of the local production cost and } \\
\text { variable neighbourhood search }\end{array}$ & $\mathrm{x}$ & $\mathrm{R}$ & big & & $\mathrm{CT}$ \\
\hline (Sokoler et al., 2014) & DW & Dantzig-Wolfe decomposition & $\mathrm{x}$ & $\mathrm{L}$ & big & & $\mathrm{CT}$ or $\mathrm{MG}$ \\
\hline (Thomas et al., 2014) & DW & $\begin{array}{l}\text { Column Generation, internal price } \\
\text { stabilisation with multiple columns stored }\end{array}$ & $\mathrm{x}$ & $\mathrm{U}$ & big & & $\mathrm{CT}$ \\
\hline (Acar et al., 2015) & HBP & Hierarchical, no negotiation & & $\mathrm{D}$ & 1 & & - \\
\hline (Albrecht et al., 2015) & DW & Dantzig-Wolfe modification & & $\mathrm{D}$ & small & $\mathrm{x}$ & MG \\
\hline (Buer et al., 2015) & $\mathrm{MH}$ & $\begin{array}{l}\text { Metropolis acceptance criterion, } \\
\text { Simulated annealing method extended by } \\
\text { a part-way reset procedure and side- } \\
\text { payments }\end{array}$ & $\mathrm{x}$ & $\mathrm{R}$ & big & $\mathrm{x}$ & SA \\
\hline (Eslikizi et al., 2015) & $\mathrm{MH}$ & $\begin{array}{l}\text { Metropolis acceptance criterion, } \\
\text { Simulated annealing method extended by } \\
\text { a part-way reset procedure and side- } \\
\text { payments }\end{array}$ & $\mathrm{x}$ & $\mathrm{R}$ & big & $\mathrm{x}$ & SA \\
\hline (Harb et al., 2015) & DW & Dantzig-Wolfe decomposition & $\mathrm{x}$ & $\mathrm{D}$ & big & & $\begin{array}{l}\mathrm{CT} \text { or } \mathrm{MG} \\
\text { or IN }\end{array}$ \\
\hline $\begin{array}{l}\text { (Homberger et al., } \\
\text { 2015) }\end{array}$ & $\mathrm{MH}$ & $\begin{array}{l}\text { Voting-based solution acceptance criteria, } \\
\text { Neighbourhood search, and side-payments } \\
\text { to avoid local solutions }\end{array}$ & $\mathrm{x}$ & $\mathrm{R}$ & big & $\mathrm{x}$ & $\mathrm{IN}$ \\
\hline (Mason et al., 2015) & DW & Dantzig-Wolfe decomposition & $\mathrm{x}$ & $\mathrm{U}$ & small & & $\mathrm{IN}$ or $\mathrm{MG}$ \\
\hline (Qu et al., 2015) & LR & Augmented Lagrangian & $\mathrm{x}$ & $\mathrm{U}$ & big & & $\mathrm{IN}$ or $\mathrm{MG}$ \\
\hline (Thomas et al., 2015) & $\mathrm{LR}$ & $\begin{array}{l}\text { Lagrangian relaxation, Volume and } \\
\text { Wedelin Algorithms. Secure-sum for } \\
\text { lower bound update }\end{array}$ & & $\mathrm{U}$ & big & & $\begin{array}{l}\text { CTor MG or } \\
\text { IN }\end{array}$ \\
\hline (Ziebuhr et al., 2015) & MH & $\begin{array}{l}\text { Simulated annealing extended by a part- } \\
\text { way reset procedure }\end{array}$ & $\mathrm{x}$ & $\mathrm{R}$ & big & & SA \\
\hline (Agnetis et al., 2016) & HBP & $\begin{array}{l}\text { Hierarchical, no negotiation, fair schedule } \\
\text { using the weighted Tchebycheff norm }\end{array}$ & & $\mathrm{U} / \mathrm{D}$ & 2 & & - \\
\hline (Bajgiran et al., 2016) & LR & $\begin{array}{l}\text { Lagrangian relaxation with subgradient } \\
\text { and heuristics to ensure a feasible solution } \\
\text { in the primal problem }\end{array}$ & $\mathrm{x}$ & $\mathrm{U}$ & big & & IN \\
\hline (Jia et al., 2016) & HBP & $\begin{array}{l}\text { Hierarchical, convergence of planning } \\
\text { counter proposals with a penalty function } \\
\text { on each iteration }\end{array}$ & & $\mathrm{U}$ & small & $\mathrm{x}$ & IN \\
\hline (Singh et al., 2016) & LR & $\begin{array}{l}\text { Lagrangian relaxation, subgradient, } \\
\text { Secure-sum Protocol and a primal } \\
\text { heuristic }\end{array}$ & $\mathrm{x}$ & $\mathrm{U}$ & big & & CTor MG \\
\hline (Tang et al., 2016b) & $\mathrm{AM}$ & Auction & $\mathrm{x}$ & $\mathrm{L}$ & big & & $\mathrm{IN}$ \\
\hline (Wenzel et al., 2016a) & LR & $\begin{array}{l}\text { Lagrangian decomposition, subgradient, } \\
\text { Recursive Quadratic Approximation }\end{array}$ & $\mathrm{x}$ & $\mathrm{D}$ & small & & CTor MG \\
\hline (Wenzel et al., 2016b) & LR & $\begin{array}{l}\text { Lagrangian decomposition, subgradient, } \\
\text { Recursive Quadratic Approximation }\end{array}$ & $\mathrm{x}$ & $\mathrm{D}$ & big & & CTor MG \\
\hline (Zoghlami et al., 2016) & HBP & $\begin{array}{l}\text { Shared discount from supplier to an } \\
\text { alternative planning }\end{array}$ & & $\mathrm{D}$ & small & $\mathrm{x}$ & IN \\
\hline
\end{tabular}

Benders decomposition approach from Benders (1962), $A M$ action mechanism, $D W$ as the Dantzig-Wolf (1960), $H B P$ Hierarchy bases protocol, $M H$ meta-heuristics $L R$ Lagrangian relaxation, $D$ downstream, $U$ upstream, L local, $B$ bottleneck, $R$ random mediator plan small defined $\leq 30, I N$ iteration number, $M G$ minimum gap, $D A$ demand allocated, $S A$ simulated annealing settings, $C T$ computer time.

\subsection{Solutions quality and novelty}

In this section, it will be collected the way in which the works evaluate the proposed solutions and novelties. It can be seen in Table 8 that in three cases a demonstration of the convergence of the proposed 
mechanism is made. In 24 of the works, a simulation is made from real cases. In the rest, a series of computational tests are carried out to verify the adequacy of the coordination mechanism used. Therefore, it is necessary to highlight the need to verify the convergence of the proposals for the coordination mechanism. In addition, to extend the behaviour analysis of the coordination mechanisms to other situations different from the simulation conditions of the specific case of a company, environment or sector, as computational tests provide some insights into the quality of solutions (Stadtler, 2007).

Regarding the novelties and drawbacks of the analysed works, these have been grouped according to the type of problem posed. Table 11 shows the works related to production scheduling. In these works, different problems of assigning tasks to different machines, in some cases with different locations, are presented. However, in none of them are dependencies or product structures.

Table 11 Value added novelties and comments on reviewed works in production scheduling.

\begin{tabular}{|c|c|}
\hline Authors & Value added/ comments \\
\hline (Agnetis et al., 2006) & $\begin{array}{l}\text { Scheduling algorithms based on the buyers' schedule proposals, the buffer capacity and the buffer cost. Overall } \\
\text { system cost is reduced only when the intermediate buffer cost is provided. }\end{array}$ \\
\hline (Attanasio et al., 2006) & $\begin{array}{l}\text { Equivalent results obtained by an auction mechanism based on a progressive Lagrangian heuristic to those provided } \\
\text { by a centralized Max-Min heuristics. }\end{array}$ \\
\hline (Jeong et al., 2009) & $\begin{array}{l}\text { Minimise total completion time on shared machines while maintaining as much autonomy of sub-production } \\
\text { systems as possible. Lagrangian multiplier is update with a modification of de Subgradient method, only with local } \\
\text { information. }\end{array}$ \\
\hline (Frazzon et al., 2010) & $\begin{array}{l}\text { They analyse from a practical test case of production and transport programming that the hierarchical coordination } \\
\text { without negotiation worsens up to a maximum of } 12 \% \text { with respect to the solution calculated by means of a } \\
\text { centralized system. }\end{array}$ \\
\hline (Lau et al., 2011) & $\begin{array}{l}\text { An adaptive price adjustment procedure for Lagrangian relaxation show better convergence properties that the } \\
\text { conventional subgradient price adjustment. }\end{array}$ \\
\hline (Singh et al., 2011) & $\begin{array}{l}\text { Lagrange relaxation solution approaches which incorporates in each iteration the direction of movement as a } \\
\text { convex combination of the current and previous subgradients. }\end{array}$ \\
\hline (Thomas et al., 2013) & $\begin{array}{l}\text { Even though the resource constraint is relaxed, a new disaggregated version of the constraint is added in the relaxed } \\
\text { formulation for each individual. Therefore, ensures that the solutions found by individual will be feasible with } \\
\text { respect to the resource constraint. }\end{array}$ \\
\hline (Behnamian, 2014) & Applied a Benders-Decomposition approach for a multi-factory scheduling. \\
\hline (Thomas et al., 2014) & $\begin{array}{l}\text { Computational experiments show that the Column Generation outperforms Lagrangian Relaxation, but the major } \\
\text { drawbacks are it has slow convergence and the high oscillation of dual prices. }\end{array}$ \\
\hline (Thomas et al., 2015) & $\begin{array}{l}\text { It proposes different algorithms to avoid the figure of the mediator and verify the impact of the exchange of } \\
\text { information. It is found that resource availability information has greater impact than production capacity } \\
\text { information. }\end{array}$ \\
\hline (Agnetis et al., 2016) & $\begin{array}{l}\text { Presents a fairness schedule between a downstream and an upstream planning proposal using the weighted } \\
\text { Tchebycheff norm, which coincides with the egalitarian solution, that is, the solution maximizing the minimum } \\
\text { payoff among the players. }\end{array}$ \\
\hline (Singh et al., 2016) & $\begin{array}{l}\text { A Secure method, on the Subgradient method, is used to exchange player information in order to update the } \\
\text { gradient with the aggregate information of all users. A heuristics is used to unsure a solution to the primal function } \\
\text { with the dual proposals. }\end{array}$ \\
\hline (Tang et al., 2016a) & $\begin{array}{l}\text { Each production cell can act as an auctioneer or a bidder with bids for time slots on machines in other cells to } \\
\text { process its own parts. }\end{array}$ \\
\hline
\end{tabular}

Source: Own elaboration.

In other papers, they have sought to coordinate different units or entities that have a restriction or a single shared resource that relates them to each other, Table12. These works focus on the restriction that relates them and not on the operations of each entity or their operations structure.

Table 12 Value added novelties and comments on reviewed works in a single coordinated restriction.

\begin{tabular}{ll}
\hline Authors & Value added/ comments \\
\hline (Pittman et al., 2007) & $\begin{array}{l}\text { The Dantzig-Wolfe decomposition or column generation as mechanism to coordinate local management in forest } \\
\text { industry, with simulated cases from real data, reduced computational times from a centralized problem. }\end{array}$
\end{tabular}


(Cheng et al., 2008)

(Kelly et al., 2008)

(Pukkala et al., 2009)

(Gunnerud et al., 2010)

(Lee et al., 2010)

(Mouret et al., 2011)

(Lu et al., 2012)

(Kovács et al., 2013)

(Sokoler et al., 2014) of dynamically decoupled subsystems. In addition, by simulation show that performs faster than CPLEX ${ }^{\circledR}$, Gurobi $^{\circledR}$ and MOSEK $^{\circledast}$ and it is able to handle much larger problems than the general purpose solvers.

Centralized model has better results but when the number of agents is increased, it is more appropriate the decentralized, although it maintains a centralized control (Dantzig-Wolfe decomposition) but does not overload by increasing with new agents.

(Harb et al., 2015 An augmented Lagrange applied to a cluster supply chain resource and service selection, with the inexact inner loop method and block coordinate descent algorithm.

(Qu et al., 2015)

(Wenzel et al., 2016a)

It presents a quadratic approximation technique for the updating of internal price that shows an improved rate of convergence compared to the subgradient-based method. It starts with subgradient method to collect solutions point in order to create the Quadratic function to update the internal price.

It presents an update of the internal price by the Subgradient method initially and then by its results extrapolates a

(Wenzel et al., 2016) quadratic regression of the relaxed restriction since they are vertices of solution of the dual main function; therefore, its minimum allows finding the new internal price.

Source: Own elaboration

Table 13 and Table 14 show the novelties of the analysed works that deal with mathematical programming for operation planning but none has used an alternative representation to Gozinto. Table 13 shows the work with models for operations planning with situations of capacity limitation, multi-product (except for the work of Dash et al. (2007)) but that do not establish the limitation that all entities know the structures of all products as in Table 14.

Table 13 Value added novelties and comments on reviewed works in operation planning coordination.

\begin{tabular}{ll}
\hline Authors & Value added/ comments \\
\hline (Dash et al., 2007) & $\begin{array}{l}\text { Continuously allocated demand without the need for a centralized information agent, and when the number of } \\
\text { participants is greater, the convergence is closer to the optimum. }\end{array}$
\end{tabular}
participants is greater, the convergence is closer to the optimum.

(Dudek et al., 2007) $\quad$ compensation are left to contract terms. The mechanism is near to optimal solution, $6.2 \%$ gap and looks for a fair distribution.

(Pibernik et al., 2007) Partial centralized and upstream planning in order to improve a downstream planning domain. It generates only a locally optimal master plan without considering the consequences for the upstream domains.

Compare different ways to perform the hierarchical coordination between centralizing sales and operations by decentralizing procurement and distribution with centralizing sales with respect to the available capacity and decentralizing production, distribution and procurement in each centre, recommending the latter on a sensitive analysis.

(Feng et al., 2008) This paper provides a decentralized supply chain planning framework for the 3PL partnership by focusing on the operational side of supply chain planning efficiency from a decentralized perspective.

(Jung et al., 2008)

Presents a combining of Lagrangian Relaxation method and Genetic Algorithms for collaborative planning and

(Nie et al., 2008) from simulation results showed an average deviation from the central optimal of $1.47 \%$. 
(Nishi et al., 2008)

(Walther et al., 2008)
The quadratic penalty term of the augmented Lagrangian is replaced by a linear penalty term. The optimality gap between the decentralized solution and an optimal central solution is within $3 \%$ for their cases.

Update the LR multiplier by a linear function inversely proportional to the iterations, with only local data and different step size. The internal prices obtained from the simulation approximate the real prices to coordinate the activities.

The exchange of information between ants of the same colony (pheromone matrix) can be extended to ants of different colonies (suppliers) in order to coordinate them.

(Silva et al., 2009)

The external customer demand is transmitted directly to the bottleneck instead of going through the downstream or upstream agent, to propose the initial planning.

(Gaudreault et al., 2010)

(Lehoux et al., 2010a)

A hierarchical downstream coordination's is improved by the share of the transport savings, letting results closer to a central coordination as Collaborative Planning, Forecasting and Replenishment proposal.

With the Vendor Managed Inventory mode, the producer is responsible for the inventory of its partner and has to maintain enough stock at the retailer site to guarantee a high service level, it lets to improve the transport cost.

(Lehoux et al., 2010b) CPFR (Collaborative Planning, Forecasting and Replenishment) generates the greatest profit for the producer while the regular replenishment mode is the most profitable strategy for the retailer. A shared profit is analysed in order to encourage partners to join a CPFR.

(Taghipour et al., 2013) Presents an improved upstream plan negotiation with a discount plan by a computational analysis.

(Kong et al., 2014) Setting the internal prices with Subgradient, in forest industry, can give the manager understanding of the values of logs in different areas and times, therefore a coordination tool.

(Lehoux et al., 2014)

The benefits obtained from a better synchronisation of the activities were not necessarily fairly distributed. In addition, that partners had difficulties to evaluate the fixed costs associated with the implementation of collaborations as well the savings that could be generated from a better coordination.

(Acar et al., 2015)

Conclude that the higher the level of demand uncertainty, the greater the benefits of integration and propose central planning for tactical and locally for scheduling.

(Albrecht et al., 2015) Propose an approach to handle a multi-period S\&OP model as long as it is a Linear Programing with no dual information required as in Dantzig-Wolfe decomposition.

(Mason et al., 2015)

A decentralized coordination on fresh product with the Dantzig-Wolfe decomposition. However, this formulation may not be as attractive for farmers due to its reduced transparency, the perceived lack of control by farmers who allow the auctioneer to define the final allocation, and where the market clearing prices are not clearly determined.

(Bajgiran et al., 2016)

It implements an algorithm to overcome the usual problem of the subgradient method that the solution proposed in the dual is not valid in the primal. It also concludes that if the decoupling points are increased, the results deteriorate with respect to a centralized solution.

Through the generation of two different plans, that is, the best profit and the best service plans, the transport operator evaluates whether his own profit should be increased by proposing a pick-up plan distinct from the delivery plan requested by the manufacturer. The 3PL shares his benefits with the manufacturer and adds a penalty function to ensure convergence to a joint plan.

(Jia et al., 2016)

\section{It presents coordination between a downstream plan and the upstream plan with a discount plan weighted by the}

$\begin{array}{ll}\text { (Zoghlami et al., 2016) } & \begin{array}{l}\text { It presents coordination between a } \\ \text { variation requested from each client. }\end{array}\end{array}$

Source: Own elaboration.

Table 14 includes a group of contributions based on the limitation that all the members of the Supply Chain know the bill of material. This limitation usually occurs in the automotive industry where the structure of the product is known throughout the suppliers. These works also stand out for their uncapacitated models except one (Reiss et al., 2014). However, all of them have limited possible alternative solutions that have to be evaluated. Among them, it should be highlight the additions of different weighting systems of fair voting by the Borda maximin or Shapley or Rawls's criterion.

Table 14 Value added novelties and comments on reviewed works in operation planning coordination uncapacitated.

\begin{tabular}{ll}
\hline Authors & Value added/ comments \\
\hline (Homberger, 2010) & The developed Simulated annealing method is based on the redundant binary coding for the MLULSP \\
$\begin{array}{l}\text { (Homberger et al., } \\
\text { 2010) }\end{array}$ & $\begin{array}{l}\text { The Borda maximin voting rule is used as a ranked-based voting rule of the proposals that are used to adapt a joint } \\
\text { pheromone matrix. }\end{array}$ \\
$\begin{array}{l}\text { (Homberger et al., } \\
\text { 2011) }\end{array}$ & $\begin{array}{l}\text { The Borda maximin voting rule, maximize the welfare level of the worst-off group member, is used to select } \\
\text { proposals and aims to avoid an early stagnation of the negotiation process }\end{array}$ \\
(Homberger, 2011) & $\begin{array}{l}\text { The mediator generates new proposals that the agents have to vote and with their votes and the Evolution } \\
\text { Algorithm, the coordination mechanism works. To measure fairness the Rawls's criterion is applied. }\end{array}$ \\
(Buer et al., 2013) & $\begin{array}{l}\text { The encoded solutions are represented by a new and simplified search graph, compared to previous works and a } \\
\text { modification of voting is used. }\end{array}$
\end{tabular}




\begin{tabular}{|c|c|}
\hline (Ziebuhr et al., 2013) & $\begin{array}{l}\text { The idea of the extended by a partway reset procedure in the Simulated Annealing is to overcome disagreements } \\
\text { between agents more easily by resetting the search once in a while to earlier solutions and discriminating some } \\
\text { agents randomly during the negotiation process. }\end{array}$ \\
\hline (Reiss et al., 2014) & $\begin{array}{l}\text { By computational tests showed that their approach outperforms upstream planning, but has some shortcomings } \\
\text { when setup times have to be considered. }\end{array}$ \\
\hline (Buer et al., 2015) & $\begin{array}{l}\text { This paper introduced an inter-organisational lot-sizing problem that some agents are able to produce the same } \\
\text { items and a side-payment with the Shapley formula. It performs better for small and medium sized instances. }\end{array}$ \\
\hline (Eslikizi et al., 2015) & $\begin{array}{l}\text { A mediator that uses simulated annealing organizes the negotiation process. In order to escape from a local } \\
\text { negotiation optimum, side payments are integrated whose calculation is based on the Shapley value. More than one } \\
\text { agent might produce items. }\end{array}$ \\
\hline $\begin{array}{l}\text { (Homberger et al., } \\
\text { 2015) }\end{array}$ & $\begin{array}{l}\text { The method considers side payments via a modified voting procedure, which temporarily accepts non-improving } \\
\text { solutions and negotiates side payments that leads to superior solutions for all agents. }\end{array}$ \\
\hline (Ziebuhr et al., 2015) & $\begin{array}{l}\text { It uses Simulated Annealing heuristics to assign products to rival agents and to coordinate production plans } \\
\text { between different suppliers. }\end{array}$ \\
\hline
\end{tabular}

Source: Own elaboration.

\section{Conclusion and future work.}

This work presents a systematic literature review of mathematical programming models with coordination mechanism for decentralised decision-making. Most of the models reviewed only consider tactical and operational levels and most problems are inter-company assuming trustful behaviour. Furthermore, the majority of the works reviewed look for a near global optimal solution. Additionally, the vast majority has used mechanism with the requirement of a mediator or a neutral agent. In addition, few of them have applied rolling horizons. The coordination mechanisms have been studied mainly without a specific sector except to the wood industry and chemical sector. The results have been tested mainly on specific cases conditions, therefore there is an opportunity to extend the coordination mechanisms to a general proposes and to applied them to others industrial sectors.

As future research line, coordination mechanism at strategic level for more than two levels must be further studied. Another research line is the evaluation of the proposed coordination mechanisms in an opportunistic behaviour. Further research is to extend to real case studies the coordination mechanisms without mediator.

If it is analysed the progress in these ten years with respect to Stadtler's (2007) conclusions, it can be emphasized that it is moving from being a subject for the research area to a ready-to-use product and one begins to glimpse its application in certain sectors such as wood and chemicals, but it still cannot be spoken about empirical research. However, there are still outstanding issues such as the analysis of fair benefits distribution among members of the supply chain, or organizational behaviour, communication or cultural aspects are mostly omitted in the design of SC schemes. The renegotiation of plans already accepted in successive rolling horizons or a holistic vision or the concept of covering several phases of collaboration have not yet been developed. Stadtler's statement that "companies are reluctant to share information and consider compensation to SC members required to achieve a mutually beneficial situation as a result of coordination" remains valid.

The work presents the limitations that only those works with access from the Universitat Politècnica de València and the commented exclusions have been analysed, so that relevant works on coordination mechanisms not included may be missing (Rius-Sorolla et al., 2017).

\section{References}

Acar, Y., \& Atadeniz, S. N. (2015). Comparison of integrated and local planning approaches for the supply network of a globally-dispersed enterprise. International Journal of Production Economics, 167, 204-219. https://doi.org/10.1016/j.ijpe.2015.05.028

Agnetis, A., Aloulou, M. A., \& Fu, L. L. (2016). Production and interplant batch delivery scheduling: Dominance and cooperation. International 
Journal of Production Economics, 182, 38-49. https://doi.org/10.1016/j.ijpe.2016.08.007

Agnetis, A., Hall, N. G., \& Pacciarelli, D. (2006). Supply chain scheduling: Sequence coordination. Discrete Applied Mathematics, 154(15), 2044-2063. https://doi.org/10.1016/j.dam.2005.04.019

Albrecht, M. (2010). Supply Chain Coordination Mechanisms. Lecture Notes in Economics and Mathematical Systems (Vol. 628). Berlin, Heidelberg: Springer Berlin Heidelberg. https://doi.org/10.1007/978-3-642-02833-5

Albrecht, M., \& Stadtler, H. (2015). Coordinating decentralized linear programs by exchange of primal information. European Journal of Operational Research, 247(3), 788-796. https://doi.org/10.1016/j.ejor.2015.06.045

Arkan, A., \& Hejazi, S. R. (2012). Coordinating orders in a two echelon supply chain with controllable lead time and ordering cost using the credit period. Computers and Industrial Engineering, 62(1), 56-69. https://doi.org/10.1016/j.cie.2011.08.016

Arshinder, Kanda, A., \& Deshmukh, S. G. (2008). Supply chain coordination: Perspectives, empirical studies and research directions. International Journal of Production Economics, 115(2), 316-335. https://doi.org/10.1016/j.ijpe.2008.05.011

Attanasio, A., Ghiani, G., Grandinetti, L., \& Guerriero, F. (2006). Auction algorithms for decentralized parallel machine scheduling. Parallel Computing, 32(9), 701-709. https://doi.org/10.1016/j.parco.2006.03.002

Badole, C. M., Jain, R., Rathore, A. P. S., \& Nepal, B. (2012). Research and Opportunities in Supply Chain Modeling: A Review. International Journal of Supply Chain Management, 1(3), 63-86.

Bajgiran, O. S., Zanjani, M. K., \& Nourelfath, M. (2016). The value of integrated tactical planning optimization in the lumber supply chain. International Journal of Production Economics, 171, 22-33. https://doi.org/10.1016/j.ijpe.2015.10.021

Behnamian, J. (2014). Multi-cut Benders decomposition approach to collaborative scheduling. International Journal of Computer Integrated Manufacturing, 28(11), 1-11. https://doi.org/10.1080/0951192X.2014.961963

Ben-Daya, M., Darwish, M., \& Ertogral, K. (2008). The joint economic lot sizing problem: Review and extensions. European Journal of Operational Research, 185(2), 726-742. https://doi.org/10.1016/j.ejor.2006.12.026

Benders, J. F. (1962). Partitioning procedures for solving mixed-variables programming problems. Numerische Mathematik, 4(1), $238-252$. https://doi.org/10.1007/BF01386316

Buer, T., Homberger, J. J., \& Gehring, H. (2013). A collaborative ant colony metaheuristic for distributed multi-level uncapacitated lot-sizing. International Journal of Production Research, 51(17), 5253-5270. https://doi.org/10.1080/00207543.2013.802822

Buer, T., Ziebuhr, M., \& Kopfer, H. (2015). A Coordination Mechanism for a Collaborative Lot-Sizing Problem with Rivaling Agents. (D. Mattfeld, T. Spengler, J. Brinkmann, \& M. Grunewald, Eds.), Logistics Management. Cham: Springer International Publishing. https://doi.org/10.1007/978-3-319-13177-1 26

Buxmann, P., Ahsen, A. Von, \& Díaz, L. M. (2008). Economic evaluation of cooperation scenarios in supply chains. Journal of Enterprise Information Management, 21(3), 247-262. https://doi.org/10.1108/17410390810866628

Chakraborty, A., \& Chatterjee, A. K. (2015). A surcharge pricing scheme for supply chain coordination under JIT environment. European Journal of Operational Research, 253(1), 14-24. https://doi.org/10.1016/j.ejor.2016.02.001

Chen, I. J., Paulraj, A., \& Lado, A. A. (2004). Strategic purchasing, supply management, and firm performance. Journal of Operations Management, 22(5), 505-523. https://doi.org/10.1016/j.jom.2004.06.002

Cheng, Forbes, J. F., San Yip, W., Fraser Forbes, J., \& Yip, W. S. (2008). Dantzig-Wolfe decomposition and plant-wide MPC coordination. Computers and Chemical Engineering, 32(7), 1507-1522. https://doi.org/10.1016/j.compchemeng.2007.07.003

Cheng, J. H. (2011). Inter-organizational relationships and information sharing in supply chains. International Journal of Information Management, 31(4), 374-384. https://doi.org/10.1016/j.ijinfomgt.2010.09.004

Cooper, M. C., Lambert, D. M., \& Pagh, J. D. (1997). Supply Chain Management: More Than a New Name for Logistics. The International Journal of Logistics Management, 8(1), 1-14. https://doi.org/10.1108/09574099710805556

Dantzig, G. B., \& Wolfe, P. (1960). Decomposition Principle for Linear Programs. Operations Research, 8(1), 101-111. https://doi.org/10.1287/opre.8.1.101

Dash, R. K., Vytelingum, P., Rogers, A., David, E., \& Jennings, N. R. (2007). Market-Based Task Allocation Mechanisms for Limited-Capacity Suppliers. IEEE Transactions on Systems, Man, and Cybernetics - Part A: Systems and Humans, 37(3), 391-405. https://doi.org/10.1109/TSMCA.2007.893474

Dudek, G., \& Stadtler, H. (2007). Negotiation-Based Collaborative Planning in Divergent Two-Tier Supply Chains. International Journal of Production Research, 45(2), 465-484.

Ertogral, K., \& David Wu, S. (2000). Auction-theoretic coordination of production planning in the supply chain. IIE Transactions, 32, 931-940. https://doi.org/10.1080/07408170008967451

Eslikizi, S., Ziebuhr, M., Kopfer, H., \& Buer, T. (2015). Shapley-based side payments and simulated annealing for distributed lot-sizing. IFACPapersOnLine, 48(3), 1592-1597. https://doi.org/10.1016/j.ifacol.2015.06.313

Fan, M., Stallaert, J., \& Whinston, A. B. (2003). Decentralized mechanism design for supply chain organizations using an auctio ... Information Systems Research, 14(1), 1-22. https://doi.org/10.1287/isre.14.1.1.14763

Feng, Y., D’Amours, S., \& Beauregard, R. (2008). The value of sales and operations planning in oriented strand board industry with make-toorder manufacturing system: Cross functional integration under deterministic demand and spot market recourse. International Journal of Production Economics, 115(1), 189-209. https://doi.org/10.1016/j.ijpe.2008.06.002

Fisher, M. L. (1985). An Applications Oriented Guide to Lagrangian Relaxation. Interfaces, 15(2), 10-21. https://doi.org/10.1287/inte.15.2.10

Fisher, M. L. (2004). The Lagrangian Relaxation Method for Solving Integer Programming Problems. Management Science, 50(12 Supplement), 1861-1871. https://doi.org/10.1287/mnsc.1040.0263

Frazzon, E., Makuschewits, T., Scholz-Reiter, B., \& Novaes, A. G. N. (2010). Assessing the integrated scheduling of manufacturing and transportation systems along global supply chains. In World conference on Transport Research. Lisbon.

Gaudreault, J., Forget, P., Frayret, J. M. J., Rousseau, A., Lemieux, S., \& D’Amours, S. (2010). Distributed operations planning in the softwood lumber supply chain: models and coordination. International Journal of Industrial Engineering: Theory, Applications and Practice, 17(3), $168-189$.

Gunnerud, V., \& Foss, B. (2010). Oil production optimization-A piecewise linear model, solved with two decomposition strategies. Computers \& Chemical Engineering, 34(11), 1803-1812. https://doi.org/10.1016/j.compchemeng.2009.10.019

Harb, H., Paprott, J. N., Matthes, P., Schütz, T., Streblow, R., \& Mueller, D. (2015). Decentralized scheduling strategy of heating systems for balancing the residual load. Building and Environment, 86, 132-140. https://doi.org/10.1016/j.buildenv.2014.12.015

Held, M., \& Karp, R. M. (1970). The Traveling-Salesman Problem and Minimum Spanning Trees. Operations Research, 18(6), 1138-1162. https://doi.org/10.1287/opre.18.6.1138

Held, M., \& Karp, R. M. (1971). The traveling-salesman problem and minimum spanning trees: Part II. Mathematical Programming, 1(1), 6-25. https://doi.org/10.1007/BF01584070

Homberger, J. (2010). Decentralized multi-level uncapacitated lot-sizing by automated negotiation. 4OR, 8(2), 155-180. https://doi.org/10.1007/s10288-009-0104-1

Homberger, J. (2011). A generic coordination mechanism for lot-sizing in supply chains. Electronic Commerce Research, 11(2), 123-149. https://doi.org/10.1007/s10660-010-9053-1 
Homberger, J., \& Gehring, H. (2011). An ant colony optimization-based negotiation approach for lot-sizing in supply chains. International Journal of Information Processing and Management, 2(3), 86-99. https://doi.org/10.4156/ijipm.vol2.issue3.10

Homberger, J., Gehring, H., \& Buer, T. (2015). Integrating Side Payments into Collaborative Planning for the Distributed Multi-level Unconstrained Lot Sizing Problem. In T. X. Bui \& R. H. Sprague (Eds.), 2015 48th Hawaii International Conference on System Sciences (Vol. 2015-March, pp. 1068-1077). IEEE. https://doi.org/10.1109/HICSS.2015.131

Homberger, J., Gehring, H., \& Ieee. (2010). A pheromone-based negotiation mechanism for lot-sizing in supply chains. In $201043 \mathrm{rd}$ Hawaii International Conference on System Sciences (pp. 1-10). IEEE. https://doi.org/10.1109/HICSS.2010.26

Huang, G. Q., Lau, J. S. K., \& Mak, K. L. (2003). The impacts of sharing production information on supply chain dynamics: A review of the literature. International Journal of Production Research, 41(7), 1483-1517. https://doi.org/10.1080/0020754031000069625

Jeong, \& Leon, V. J. (2002). Decision-making and cooperative interaction via coupling agents in organizationally distributed systems. IIE Transactions (Institute of Industrial Engineers), 34(9), 789-802. https://doi.org/10.1023/A:1015548705266

Jeong, \& Yim, S. B. (2009). A job shop distributed scheduling based on Lagrangian relaxation to minimise total completion time. International Journal of Production Research, 47(24), 6783-6805. https://doi.org/10.1080/00207540701824217

Jia, Z. Z., Deschamps, J. C., \& Dupas, R. (2016). A negotiation protocol to improve planning coordination in transport-driven supply chains. Journal of Manufacturing Systems, 38, 13-26. https://doi.org/10.1016/j.jmsy.2015.10.003

Jung, H., Chen, F. F., \& Jeong, B. (2008). Decentralized supply chain planning framework for third party logistics partnership. Computers \& Industrial Engineering, 55(2), 348-364. https://doi.org/10.1016/j.cie.2007.12.017

Katok, E., \& Pavlov, V. (2013). Fairness in supply chain contracts: A laboratory study. Journal of Operations Management, 31 (3), $129-137$. https://doi.org/10.1016/j.jom.2013.01.001

Kelly, J. D., \& Zyngier, D. (2008). Hierarchical decomposition heuristic for scheduling: Coordinated reasoning for decentralized and distributed decision-making problems. Computers \& Chemical Engineering, 32(11), 2684-2705. https://doi.org/10.1016/j.compchemeng.2007.08.007

Kong, J., \& Rönnqvist, M. (2014). Coordination between strategic forest management and tactical logistic and production planning in the forestry supply chain. International Transactions in Operational Research, 21(5), 703-735. https://doi.org/10.1111/itor.12089

Kovács, A., Egri, P., Kis, T., \& Váncza, J. (2013). Inventory control in supply chains: Alternative approaches to a two-stage lot-sizing problem. International Journal of Production Economics, 143(2), 385-394. https://doi.org/10.1016/j.ijpe.2012.01.001

Kumar, B. K., Nagaraju, D., \& Narayanan, S. (2016). Supply Chain Coordination Models: A Literature Review. Indian Journal of Science and Technology, 9(38). https://doi.org/10.17485/ijst/2016/v9i38/86938

Kutanoglu, E., \& David Wu, S. (1999). On combinatorial auction and Lagrangean relaxation for distributed resource scheduling. IIE Transactions, 31(9), 813-826. https://doi.org/10.1080/07408179908969883

Lau, H. C., Zhao, Z. J., Ge, S. S., \& Lee, T. H. (2011). Allocating resources in multiagent flowshops with adaptive auctions. IEEE Transactions on Automation Science and Engineering, 8(4), 732-743. https://doi.org/10.1109/TASE.2011.2160536

Lee, \& Jeong, I. J. (2010). A distributed coordination for a single warehouse-multiple retailer problem under private information. International Journal of Production Economics, 125(1), 190-199. https://doi.org/10.1016/j.ijpe.2010.02.001

Lehoux, N., D’Amours, S., Frein, Y., Langevin, A., \& Penz, B. (2010a). Collaboration for a two-echelon supply chain in the pulp and paper industry: the use of incentives to increase profit. Journal of the Operational Research Society, 62(4), 581-592. https://doi.org/10.1057/jors.2009.167

Lehoux, N., D'Amours, S., \& Langevin, A. (2010b). A win-win collaboration approach for a two-echelon supply chain: a case study in the pulp and paper industry. European J. of Industrial Engineering, 4(4), 493. https://doi.org/10.1504/EJIE.2010.035656

Lehoux, N., D'Amours, S., \& Langevin, A. (2014). Inter-firm collaborations and supply chain coordination: review of key elements and case study. Production Planning \& Control, 25(10), 858-872. https://doi.org/10.1080/09537287.2013.771413

Li, X., \& Wang, Q. (2007). Coordination mechanisms of supply chain systems. European Journal of Operational Research, $179(1), 1-16$. https://doi.org/10.1016/j.ejor.2006.06.023

Lu, S. Y. P., Lau, H. Y. K., \& Yiu, C. K. F. (2012). A hybrid solution to collaborative decision-making in a decentralized supply-chain. Journal of Engineering and Technology Management, 29(1), 95-111. https://doi.org/10.1016/j.jengtecman.2011.09.008

Mahdiraji, H. A., Zavadskas, E. K., \& Hajiagha, S. H. R. (2015). Game theoretic approach for coordinating unlimited multi echelon supply chains. Transformations in Business and Economics, 14(2), 133-151.

Maheut, J., Besga, J. M., Uribetxebarria, J., \& Garcia-Sabater, J. P. (2014a). A decision support system for modelling and implementing the supply network configuration and operations scheduling problem in the machine tool industry. Production Planning \& Control, 25(8), 679-697. https://doi.org/10.1080/09537287.2013.798087

Maheut, J., Garcia-Sabater, J. P., Garcia-Sabater, J. J., \& Marin-Garcia, J. (2014b). Coordination Mechanism for MILP Models to Plan Operations Within an Advanced Planning and Scheduling System in a Motor Company: A Case Study. In Annals of Industrial Engineering 2012 (pp. 245-253). London: Springer London. https://doi.org/10.1007/978-1-4471-5349-8 29

Manrodt, K. B., \& Vitasek, K. (2004). Global Process Standardization: a Case Study. Journal of Business Logistics, $25(1)$, 1-23. https://doi.org/10.1002/j.2158-1592.2004.tb00168.x

Marin-Garcia, J. A., Ramirez Bayarri, L., \& Atares Huerta, L. (2015). Protocol: Comparing advantages and disadvantages of Rating Scales, Behavior Observation Scales and Paired Comparison Scales for behavior assessment of competencies in workers. A systematic literature review. Working Papers on Operations Management, 6(2), 49. https://doi.org/10.4995/wpom.v6i2.4032

Mason, A. N., \& Villalobos, J. R. (2015). Coordination of perishable crop production using auction mechanisms. Agricultural Systems, 138, 1830. https://doi.org/10.1016/j.agsy.2015.04.008

McAfee, R. P., \& McMillan, J. (1987). Auctions and Bidding. Journal of Economic Literature, 25(2), 699-738.

Medina-Lopez, C., Marin-Garcia, J. A., \& Alfalla-Luque, R. (2010). Una propuesta metodológica para la realización de búsquedas sistemáticas de bibliografía (A methodological proposal for the systematic literature review). Working Papers on Operations Management, 1(2). https://doi.org/10.4995/wpom.v1i2.786

Mouret, S., Grossmann, I. E., \& Pestiaux, P. (2011). A new Lagrangian decomposition approach applied to the integration of refinery planning and crude-oil scheduling. Computers \& Chemical Engineering, 35(12), 2750-2766. https://doi.org/10.1016/j.compchemeng.2011.03.026

Mula, J., Peidro, D., Díaz-Madroñero, M., \& Vicens, E. (2010). Mathematical programming models for supply chain production and transport planning. European Journal of Operational Research, 204(3), 377-390. https://doi.org/10.1016/j.ejor.2009.09.008

Nie, L., Xu, X., \& Zhan, D. (2008). Collaborative planning in supply chains by lagrangian relaxation and genetic algorithms. International Journal of Information Technology \& Decision Making, 7(1), 183-197. https://doi.org/10.1142/s0219622008002879

Nishi, T., Shinozaki, R., \& Konishi, M. (2008). An Augmented Lagrangian Approach for Distributed Supply Chain Planning for Multiple Companies. IEEE Transactions on Automation Science and Engineering, 5(2), 259-274. https://doi.org/10.1109/TASE.2007.894727

Ouelhadj, D., \& Petrovic, S. (2009). A survey of dynamic scheduling in manufacturing systems. Journal of Scheduling, 12(4), 417-431. https://doi.org/10.1007/s10951-008-0090-8

Pibernik, R., \& Sucky, E. (2007). An approach to inter-domain master planning in supply chains. International Journal of Production Economics, 108(1-2), 200-212. https://doi.org/10.1016/j.ijpe.2006.12.010 
Pittman, S. D., Bare, B. B., \& Briggs, D. G. (2007). Hierarchical production planning in forestry using price-directed decomposition. Canadian Journal of Forest, 37(10), 2010-2021. https://doi.org/10.1139/X07-026

Polyak, B. T. (1969). Minimization of unsmooth functionals. USSR Computational Mathematics and Mathematical Physics, 9(3), 14-29. https://doi.org/10.1016/0041-5553(69)90061-5

Pukkala, T., Heinonen, T., \& Kurttila, M. (2009). An application of a reduced cost approach to spatial forest planning. Forest Science, 55(1), 1322.

Qu, T., Nie, D. X., Chen, X., Chen, X. D., Dai, Q. Y., \& Huang, G. Q. (2015). Optimal configuration of cluster supply chains with augmented Lagrange coordination. Computers and Industrial Engineering, 84(SI), 43-55. https://doi.org/10.1016/j.cie.2014.12.026

Reiss, F., \& Buer, T. (2014). A coordination mechanism for capacitated lot-sizing in non-hierarchical n-tier supply chains. 2014 Ieee Symposium on Computational Intelligence in Production and Logistics Systems (Cipls), 9-15. https://doi.org/10.1109/CIPLS.2014.7007155

Rius-Sorolla, G., Maheut, J., Estelles-Miguel, S., \& Garcia-Sabater, J. P. (2017). Protocol: Systematic Literature Review on coordination mechanisms for the mathematical programming models in production planning with decentralized decision making. WPOM-Working Papers on Operations Management, 8(2), 22. https://doi.org/10.4995/wpom.v8i2.7858

Sahin, F., \& Robinson, E. P. P. (2002). Flow Coordination and Information Sharing in Supply Chains : Review , Implications , and Directions for Future Research. Decision Sciences, 33(4), 505-535. https://doi.org/10.1111/j.1540-5915.2002.tb01654.X

Silva, C. A., Sousa, J. M. C., Runkler, T. A., \& Sá da Costa, J. . (2009). Distributed supply chain management using ant colony optimization. European Journal of Operational Research, 199(2), 349-358. https://doi.org/10.1016/j.ejor.2008.11.021

Simatupang, T., \& Sridharan, R. (2006). The collaboration index: a measure for supply chain collaboration. International Journal of Physical Distribution \& Logistics Management, 35, 44-62. https://doi.org/10.1108/09600030510577421

Singh, G., \& Ernst, A. (2011). Resource constraint scheduling with a fractional shared resource. Operations Research Letters, 39(5), 363-368. https://doi.org/10.1016/j.orl.2011.06.003

Singh, G., \& O'Keefe, C. M. (2016). Decentralised scheduling with confidentiality protection. Operations Research Letters, 44(4), $514-519$. https://doi.org/10.1016/j.orl.2016.05.004

Sokoler, L. E., Standardi, L., Edlund, K., Poulsen, N. K., Madsen, H., \& Jørgensen, J. B. (2014). A Dantzig-Wolfe decomposition algorithm for linear economic model predictive control of dynamically decoupled subsystems. Journal of Process Control, 24(8), $1225-1236$. https://doi.org/10.1016/j.jprocont.2014.05.013

Sridharan, R., \& Simatupang, T. M. (2009). Managerial Views of Supply Chain Collaboration. Gadjah Mada International Journal of Business, $11(2), 253-273$

Stadtler, H. (2007). A framework for collaborative planning and state-of-the-art. OR Spectrum, 31(1), 5-30. https://doi.org/10.1007/s00291-0070104-5

Stadtler, H., \& Kilger, C. (2008). Supply Chain Management and Advanced Planning. (H. Stadtler \& C. Kilger, Eds.), Supply Chain Management and Advanced Planning. Concepts, Models, Software, and Case Studies. Springer.

Stank, T. P., Goldsby, T. J., \& Vickery, S. K. (1999). Effect of service supplier performance on satisfaction and loyalty of store managers in the fast food industry. Journal of Operations Management, 17(4), 429-447. https://doi.org/10.1016/S0272-6963(98)00052-7

Taghipour, A., \& Frayret, J. M. (2013). An algorithm to improve operations planning in decentralized supply chains. In 2013 International Conference on Advanced Logistics and Transport, ICALT 2013 (pp. 100-103). https://doi.org/10.1109/ICAdLT.2013.6568442

Tang, S. H., Rahimi, I., \& Karimi, H. (2016a). Objectives, products and demand requirements in integrated supply chain network design: a review. International Journal of Industrial and Systems Engineering, 23(2), 181. https://doi.org/10.1504/IJISE.2016.076399

Tang, Zeng, C., \& Pan, Z. (2016b). Auction-based cooperation mechanism to parts scheduling for flexible job shop with inter-cells. Applied Soft Computing, 49, 590-602. https://doi.org/10.1016/j.asoc.2016.08.046

Thomas, A., Krishnamoorthy, M., Singh, G., \& Venkateswaran, J. (2015). Coordination in a multiple producers-distributor supply chain and the value of information. International Journal of Production Economics, 167, 63-73. https://doi.org/10.1016/j.ijpe.2015.05.020

Thomas, A., Singh, G., Krishnamoorthy, M., \& Venkateswaran, J. (2013). Distributed optimisation method for multi-resource constrained scheduling in coal supply chains. International Journal of Production Research, 51(9), 2740-2759. https://doi.org/10.1080/00207543.2012.737955

Thomas, A., Venkateswaran, J., Singh, G., \& Krishnamoorthy, M. (2014). A resource constrained scheduling problem with multiple independent producers and a single linking constraint: A coal supply chain example. European Journal of Operational Research, $236(3), 946-956$. https://doi.org/10.1016/j.ejor.2013.10.006

VICS. (2004). Collaborative Planning, Forecasting and Replenishment. Retrieved from https://www.gs1us.org/

Vitasek, K. (2016). Strategic sourcing business models. Strategic Outsourcing: An International Journal, 9(2), 126-138. https://doi.org/10.1108/SO-02-2016-0003

Walther, G., Schmid, E., \& Spengler, T. S. (2008). Negotiation-based coordination in product recovery networks. International Journal of Production Economics, 111(2), 334-350. https://doi.org/10.1016/j.ijpe.2006.12.069

Wang, L., Pfohl, H. christian, Berbner, U., \& Keck, A. K. (2016). Supply Chain Collaboration or Conflict? Information Sharing and Supply Chain Performance in the Automotive Industry. In Comercial Transport (pp. 303-318). Springer, Cham. https://doi.org/10.1007/978-3319-21266-1

Wenzel, S., Paulen, R., Krämer, S., Beisheim, B., \& Engell, S. (2016a). Shared resource allocation in an integrated petrochemical site by pricebased coordination using quadratic approximation. In 2016 European Control Conference, ECC 2016 (pp. 1045-1050). https://doi.org/10.1109/ECC.2016.7810427

Wenzel, S., Paulen, R., Stojanovski, G., Kraemer, S., Beisheim, B., \& Engell, S. (2016b). Optimal resource allocation in industrial complexes by distributed optimization and dynamic pricing. At - Automatisierungstechnik, 64(6), 428-442. https://doi.org/10.1515/auto-2016-0003

Whang, S. (1995). Coordination in operations: A taxonomy. Journal of Operations Management, 12(3-4), $413-422$. https://doi.org/10.1016/0272-6963(95)00010-P

Zhou, H., \& W C Benton, J. (2007). Supply chain practice and information sharing. Journal of Operations Management, 25(6), 1348-1365. https://doi.org/10.1016/j.jom.2007.01.009

Ziebuhr, M., Buer, T., \& Kopfer, H. (2013). Agent-negotiation of lot-sizing contracts by simulated annealing with part-way resets. In Lecture Notes in Computer Science (including subseries Lecture Notes in Artificial Intelligence and Lecture Notes in Bioinformatics) (Vol. 8076 LNAI). https://doi.org/10.1007/978-3-642-40776-5-16

Ziebuhr, M., Buer, T., \& Kopfer, H. (2015). A Collaborative Lot-Sizing Problem with Production Limitations. 2015 Ieee Symposium Series on Computational Intelligence (Ieee Ssci), 1005-1012. https://doi.org/10.1109/ssci.2015.146

Zoghlami, N., Taghipour, A., Merlo, C., \& Abed, M. (2016). Management of divergent production network using decentralised multi-level capacitated lot-sizing models. International Journal of Shipping and Transport Logistics, 8(5), 590-604. https://doi.org/10.1504/ijstl.2016.10000270 